\title{
Phospholipidation of nuclear proteins by the human papillomavirus E6 oncoprotein: implication in carcinogenesis
}

\author{
Benjamin Marx¹, Martin Hufbauer ${ }^{1}$, Paola Zigrino², Slawomir Majewski ${ }^{3}$ Birgid \\ Markiefka ${ }^{4}$, Timo Sachsenheimer ${ }^{5}$, Britta Brügger ${ }^{5}$ and Baki Akgül ${ }^{1}$ \\ ${ }^{1}$ Institute of Virology, University of Cologne, Cologne, Germany \\ ${ }^{2}$ Department of Dermatology and Venereology, University Hospital Cologne, Cologne, Germany \\ ${ }^{3}$ Department of Dermatology and Venereology, Medical University of Warsaw, Warsaw, Poland \\ ${ }^{4}$ Institute of Pathology, University Hospital Cologne, Cologne, Germany \\ ${ }^{5}$ Heidelberg University Biochemistry Center (BZH), Heidelberg, Germany \\ Correspondence to: Baki Akgül, email: baki.akguel@uk-koeln.de \\ Keywords: human papillomavirus; E6 oncoprotein; phosphatidylinositides; nuclear phosphatidylinositol-4,5-bisphosphate; skin cancer \\ Received: June 30, $2018 \quad$ Accepted: September 06, $2018 \quad$ Published: September 25, 2018 \\ Copyright: Marx et al. This is an open-access article distributed under the terms of the Creative Commons Attribution License 3.0 \\ (CC BY 3.0), which permits unrestricted use, distribution, and reproduction in any medium, provided the original author and source \\ are credited.
}

\section{ABSTRACT}

Phospholipids regulate numerous cellular functions and their deregulation is known to be associated with cancer development. Here, we show for the first time that expression of the E6 oncoprotein of human papillomavirus type 8 (HPV8) leads to a profound increase in nuclear phosphatidylinositol-4,5-bisphosphate $\left(\mathrm{PI}(4,5) \mathrm{P}_{2}\right)$ lipid levels in monolayer cultures, that led to an aberrant phospholipidation of cellular proteins. Elevated $\mathrm{PI}(4,5) \mathrm{P}_{2}$ levels in organotypic skin cultures, skin tumors of K14HPV8-E6 transgenic mice as well as HPV8 positive skin carcinomas highly suggest a decisive role of $\mathrm{PI}(4,5) \mathrm{P}_{2}$ in $\mathrm{HPV}$ associated squamous-cell-carcinoma development. Furthermore, mass-spectrometric analysis confirmed an increase of $\mathrm{PI}(4,5) \mathrm{P}_{2}$, which was characterized by a shift in the distribution of lipid species. $\mathrm{PI}(4,5) \mathrm{P}_{2}$ upregulation was independent of E6 interference with MAML1. However, E6 does interfere with the $\mathrm{PI}(4,5) \mathrm{P}_{2}$ metabolic pathway by upregulation of phosphatidylinositol-4-phosphate5-kinase type I and phosphatidylinositol-5-phosphate 4-kinase type II as well as the binding to 5'-phosphatase OCRL and phosphatidylinositol. All of these mechanisms combined may contribute to $\mathrm{PI}(4,5) \mathrm{P}_{2}$ elevation in $\mathrm{E} 6$ positive cells. The identification of CAND1 and SND1 - two proteins known to be involved in carcinogenic processes were significantly stronger phospholipidized in the presence of E6. In conclusion we provide evidence that the modulation of the $\mathrm{PI}(4,5) \mathrm{P}_{2}$ metabolism is a novel oncogenic mechanism relevant for HPV-induced carcinogenesis.

\section{INTRODUCTION}

Human papillomaviruses (HPVs) are DNA viruses infecting both mucosa and skin, where they can persist asymptomatically or cause keratinocyte cancer. Highrisk HPVs of genus alphapapillomavirus (alphaPV, e.g. HPV16) are the established cause of cervical intraepithelial neoplasia $(\mathrm{CIN})$ and their progression to cervical cancer [1]. Also, epidemiological as well as experimental data support a carcinogenic role of HPV of genus betapapillomavirus
(betaPV, e.g. HPV8) in the development of squamous cell skin carcinoma (SCC), especially in high-risk patient groups such as immunosuppressed organ transplant recipients [2-4]. Initial evidence for a role of cutaneous HPVs in the pathogenesis of skin malignancies arose from the identification of HPV5 and HPV8 in patients suffering from the rare genetic disorder Epidermodysplasia verruciformis $(\mathrm{EV})$. EV is characterized by diffuse, wartlike lesions with broad areas of the skin being frequently transformed into carcinomas early in life [5]. Functional 
studies on betaPV early gene products showed that the viral E6 oncoprotein inhibits apoptosis and DNA damage repair following UV irradiation [6, 7]. In addition to the disruption of the cellular UV response, E6 also has the capacity to bind the Mastermind-like protein 1 (MAML1), thus inhibiting NOTCH-dependent keratinocyte differentiation [8-10]. Moreover, the ability of E6 to bind MAML1 has proven to be a required prerequisite for skin papilloma formation in mouse papillomavirus type 1 infected mice [11]. When expressed in transgenic mice under the control of the keratin-14 promoter (K14HPV8-E6), HPV8-E6 induces the development of papillomas - partially with moderate to severe dysplasia and SCC. A single UVA/B treatment of the skin induced papillomatosis in K14-HPV8-E6 mice within 3 weeks [12]. The persistence of UV damaged cells in these mice was identified as crucial for skin tumorigenesis [13].

The E6 proteins of high-risk alphaPV are characterized by the presence of a PDZ-binding motif (PSD95-DLG1-ZO-1) through which they interact with a number of cellular PDZ domain-containing substrates and cooperate in their degradation. The ability of these E6 proteins to bind to PDZ domain proteins correlates with the oncogenic potential of the virus $[14,15]$. Since the E6 proteins of oncogenic betaPV do not encode a PDZbinding motif no cellular PDZ protein is known to be targeted for degradation. However, we recently identified the PDZ domain protein Syntenin-2 to be transcriptionally downregulated by E6, but not by E7 of HPV8 [16]. Syntenin-2 is known to interact with high affinity with phosphatidylinositol-4-5-bisphosphate $\quad\left(\mathrm{PI}(4,5) \mathrm{P}_{2}\right)$ [17]. Recent studies have implied an association of phosphoinositides and their metabolizing enzymes with various pathophysiological conditions, including cancer [18]. $\mathrm{PI}(4,5) \mathrm{P}_{2}$ is a minor lipid that binds and regulates the activity of various proteins. Nuclear $\mathrm{PI}(4,5) \mathrm{P}_{2}$ is regulated independently of the cytoplasmic phosphoinositide pool [19], and has been localized to nucleoli and nuclear speckles (also known as interchromatin granule clusters) $[20,21]$, which are nuclear domains enriched in pre-mRNA splicing factors, located in the interchromatin regions of the nucleoplasm of mammalian cells [22]. Nuclear $\mathrm{PI}(4,5) \mathrm{P}_{2}$ levels are altered in response to numerous cellular stimuli, strongly supporting the notion of $\mathrm{PI}(4,5) \mathrm{P}_{2}$ acting as a direct messenger that binds and regulates nuclear effectors $[19,23,24]$. Recent studies have revealed that nuclear $\mathrm{PI}(4,5) \mathrm{P}_{2}$ can directly bind and regulate functions of nuclear proteins involved in multiple processes, including transcription, mRNA processing and export, chromatin remodeling, stress responses, DNA repair as well as mitosis (reviewed in $[25,26]$ ). However, the exact role of nuclear $\mathrm{PI}(4,5) \mathrm{P}_{2}$ in epidermal cancer development still needs to be resolved [21, 27]. Yet, in this study we now demonstrate for the first time that HPV targets the $\mathrm{PI}(4,5) \mathrm{P}_{2}$ metabolic pathway, leading to enhanced phospholipidation of nuclear proteins in skin keratinocytes.
Taken together, our experimental results provide evidence for a novel oncogenic mechanism relevant for HPV induced carcinogenic processes in keratinocytes.

\section{RESULTS}

\section{Expression of HPV8-E6 increases nuclear $\mathrm{PI}(4,5) \mathrm{P}_{2}$}

To test whether $\mathrm{PI}(4,5) \mathrm{P}_{2}$ is detectable in skin keratinocytes, total cell extracts of N/TERT cells (N/ TERTs) grown either in KGM-Gold (low calcium media; ${ }^{\mathrm{KGM} N}$ /TERTs) or in $\mathrm{RM}^{+}$media (high calcium media; ${ }^{\mathrm{RM}}{ }^{+} \mathrm{N} /$ TERTs) were generated [28]. This cell line derived from foreskin keratinocytes and was immortalized through overexpression of the catalytic subunit of human telomerase [29]. Western blots were performed using the mouse monoclonal anti-PI(4,5) $\mathrm{P}_{2}-\mathrm{IgM}$ antibody that specifically detects $\mathrm{PI}(4,5) \mathrm{P}_{2}[30]$. Surprisingly, despite the fact that $\mathrm{PI}(4,5) \mathrm{P}_{2}$ is a very tiny molecule and should therefore only have been detectable at the dye front in SDS-PAGEs, the $\mathrm{PI}(4,5) \mathrm{P}_{2}$ specific antibody unexpectedly recognized multiple protein bands in the range of $75-150 \mathrm{kDa}$ in KGMN/TERTs, which were absent in ${ }^{\mathrm{RM}+} \mathrm{N} / \mathrm{TERTs}$ (Figure 1A). This observation implies that KGMN/TERTs with basal cell characteristics may contain proteins bound to $\mathrm{PI}(4,5) \mathrm{P}_{2}$. To address the question whether $\mathrm{PI}(4,5) \mathrm{P}_{2}$ signals might be dependent on keratinocyte differentiation,

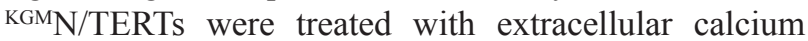
$(2 \mathrm{mM}$ ) for up to 8 days. As shown in Figure 1B, Loricrin (a marker for terminal keratinocyte differentiation) was expressed 5 days following calcium exposure. Furthermore, keratinocyte differentiation was paralleled by a decrease of $\mathrm{PI}(4,5) \mathrm{P}_{2}$-bound protein bands. Most intriguingly, the expression of HPV8-E6 in ${ }^{\mathrm{KGM} N} \mathrm{~N} / \mathrm{TERTs}$ ( $\left.{ }^{\text {KGMN}} \mathrm{N} / \mathrm{TERT}-8 \mathrm{E} 6\right)$ led to significantly stronger $\mathrm{PI}(4,5) \mathrm{P}_{2}$ bound protein band signals when compared to matched control (Figure 1C).

The specificity of the anti-PI(4,5) $\mathrm{P}_{2}$ antibody (clone $2 \mathrm{C} 11)$ has been proven in other studies before [30, 31]. Pre-incubation of the 2C11 antibody with an excess of liposomes containing different phosphoinositides showed that this lipid oversaturation led to an abrogation of specific staining of $\mathrm{PI}(4,5) \mathrm{P}_{2}[30,31]$. Furthermore, in another study it was shown that $\mathrm{PI}(4,5) \mathrm{P}_{2}$ binding of $2 \mathrm{C} 11$ was effectively prevented by neomycin, an aminoglycoside antibiotic that binds with high affinity to several phosphoinositides [21]. To further confirm that the observed Western blot signals were $\mathrm{PI}(4,5) \mathrm{P}_{2}$ specific, we also conducted experiments to confirm the specificity of $2 \mathrm{C} 11$ for $\mathrm{PI}(4,5) \mathrm{P}_{2}$. To this end, we added neomycin while blocking the membranes, and also observed an absence of protein bands compared to untreated blots (Figure 1D). Additionally, $\mathrm{PI}(4,5) \mathrm{P}_{2}$ signals in Western blots also disappeared following pre-incubation of cell extracts with phospholipase $\mathrm{C}$, an enzyme that hydrolyzes $\mathrm{PI}(4,5) \mathrm{P}_{2}$ to 
diacylglycerol and inositol-(1,4,5)-triphosphate. All these experiments further underpinned the specificity of the antibody signal (Figure 1E).

Mass-spectrometric analysis of phosphoinositide species showed an increase of both mono- and bisphosphorylated phosphoinositides in HPV8-E6 expressing N/TERTs (Figure 1F). The increase of $\mathrm{PI}(4,5) \mathrm{P}_{2}$ was accompanied by a shift in lipid species distribution identified by mass-spectrometric analysis. In the presence of HPV8-E6 expression polyunsaturated PIP and PIP $_{2}$ lipid species $38: 4$ and $38: 3$, mainly comprised of the fatty acyl combinations 18:0/20:4 for lipid species 38:4 and 18:0/20:3 for lipid species $38: 3$, were both significantly elevated, predominantly at the expense of monounsaturated phosphoinositide depletion (Figure $1 \mathrm{G}-1 \mathrm{H}$ ). Taken together, our data strongly suggest that HPV8-E6 enforces a basal cell-like keratinocyte phenotype, characterized by $\mathrm{PI}(4,5) \mathrm{P}_{2}$ enrichment.

\section{High nuclear PI(4,5) $\mathrm{P}_{2}$ levels in HPV8-E6 positive keratinocytes and transgenic murine skin}

In addition to Western blot results, immunofluorescence staining also clearly showed a significant $\mathrm{PI}(4,5) \mathrm{P}_{2}$ upregulation, mainly located in the nucleus in ${ }^{\mathrm{KGM}} \mathrm{N} / \mathrm{TERT}-8 \mathrm{E} 6$ cells cultured as monolayers (Figure 2A). In organotypic skin cultures of primary human keratinocytes (PHK) only weak $\mathrm{PI}(4,5) \mathrm{P}_{2}$ specific signals were detected in cultures of wild-type (wt) keratinocytes, or keratinocytes expressing the empty retroviral vector $\mathrm{pLXSN}$. In contrast, strong $\mathrm{PI}(4,5)$ $\mathrm{P}_{2}$ fluorescence signals were detected in E6 positive keratinocytes throughout the regenerated epithelial keratinocyte layers (Figure 2B).

In addition to organotypic cultures, $\mathrm{PI}(4,5) \mathrm{P}_{2}$ levels were also evaluated in untreated and UVA/B-irradiated $\mathrm{FVB} / \mathrm{n}$-wt as well as K14-HPV8-E6 transgenic murine skin. No $\mathrm{PI}(4,5) \mathrm{P}_{2}$ specific signals were found in the untreated $\mathrm{FVB} / \mathrm{n}$-wt epidermis, whereas isolated signals could be detected in untreated K14-HPV8-E6 skin. Thirteen days post UV-exposure, both mouse strains developed skin hyperplasia, which was paralleled by high nuclear $\mathrm{PI}(4,5) \mathrm{P}_{2}$ levels in epithelial cell layers. Twentyfour days post treatment, $\mathrm{FVB} / \mathrm{n}$-wt skin had fully healed from UV induced hyperplasia and did not show any signs of nuclear $\mathrm{PI}(4,5) \mathrm{P}_{2}$ anymore, whereas - in K14HPV8-E6 mice hyperplasia led to skin tumor formation - with persistent high levels of $\mathrm{PI}(4,5) \mathrm{P}_{2}$ in the nucleus throughout the epithelium (Figure 3).

\section{High PI $(4,5) \mathrm{P}_{2}$ levels in HPV positive clinical samples}

Having demonstrated, that nuclear $\mathrm{PI}(4,5) \mathrm{P}_{2}$ levels rise upon HPV8-E6 expression, $\mathrm{PI}(4,5) \mathrm{P}_{2}$ levels were next studied in normal human skin as well as in SCCs of the general population, generally associated with low viral load, and in lesions of EV-patients, characterized by productive HPV infection and high viral loads. While no staining was found in healthy human skin or SCCs with low viral loads, strong nuclear localization of $\mathrm{PI}(4,5) \mathrm{P}_{2}$ was detected throughout the HPV8 positive EV-tumor (Figure 4A). To exclude that the observed high $\mathrm{PI}(4,5) \mathrm{P}_{2}$ levels might not be associated with other skin cancer types, such as melanoma, basal cell carcinoma, or Merkel cell polyomavirus positive Merkel cell carcinomas, these cancers were further assessed by performing immunofluorescence staining. As none of the additionally tested three skin cancer types had shown any signal of $\mathrm{PI}(4,5) \mathrm{P}_{2}$ (Figure 4B), the increase of $\mathrm{PI}(4,5) \mathrm{P}_{2}$ is specific for betaPV-induced skin carcinogenesis. To further evaluate whether HPV16 may also cause $\mathrm{PI}(4,5) \mathrm{P}_{2}$ enrichment, we next analyzed $\mathrm{PI}(4,5) \mathrm{P}_{2}$ levels in tissuemicro-arrays of HPV16 positive cervical intraepithelial neoplasia (CIN) and cervical cancers. By monitoring HPV16 gene expression in low-grade CIN and cervical cancers, Böhm et al. already demonstrated several years ago that in low-grade lesions E6 transcripts were only detected in the upper third of the epithelium with no significant differences between the viral transcription pattern in high-grade CIN and invasive carcinoma [32]. In healthy cervical epithelium, no $\mathrm{PI}(4,5) \mathrm{P}_{2}$ signals were detected. However, there were markedly increased $\mathrm{PI}(4,5) \mathrm{P}_{2}$ signals in the upper most layers of CIN I, in the basal layers of CIN II, throughout the epithelium in CIN III and cervical cancer tissue (Figure 5). The staining pattern of nuclear $\mathrm{PI}(4,5) \mathrm{P}_{2}$ is therefore in accordance with E6 expression in cervical tissues. To summarize, elevated $\mathrm{PI}(4,5) \mathrm{P}_{2}$ levels are a common phenomenon in oncogenic alphaPV and betaPV infected keratinocytic lesions.

\section{HPV 8-E6 mediated enrichment of $\operatorname{PI}(4,5) \mathrm{P}_{2}$ is independent from deregulated NOTCH effects}

The betaPV E6 proteins can bind to MAML1, a transcriptional co-activator of NOTCH regulated genes. Binding of E6 to MAML1 blocks NOTCH-dependent keratinocyte differentiation [8-10]. To determine whether the increase of $\mathrm{PI}(4,5) \mathrm{P}_{2}$ may not simply result from E6-mediated disruption of the normal keratinocyte differentiation pathway, originating from interruption of the NOTCH signaling pathway, a series of HPV8-E6 mutants was generated with mutations altering conserved residues in betaPV E6. All mutant proteins were found to be stably expressed in transiently transfected C33a cells. Flag-tagged HPV8-E6wt and all other single mutants were able to bind MAML1. Interestingly, the double mutant L61A/W63A completely lost the ability to complex with MAML1 (Figure 6A). To analyze, whether the absent binding to MAML1 might result in $\mathrm{PI}(4,5) \mathrm{P}_{2}$ upregulation, the single mutants L61 A and W63A as well as the double mutant $\mathrm{L} 61 \mathrm{~A} / \mathrm{W} 63 \mathrm{~A}$ were sub-cloned into the retroviral 
A

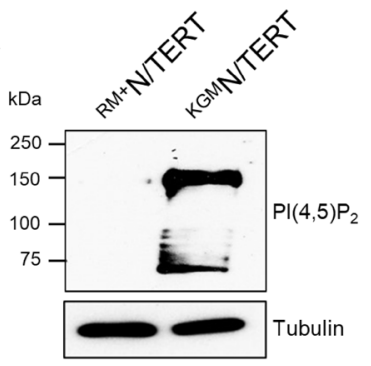

D

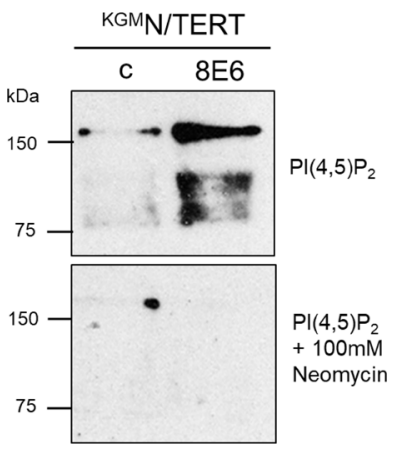

B

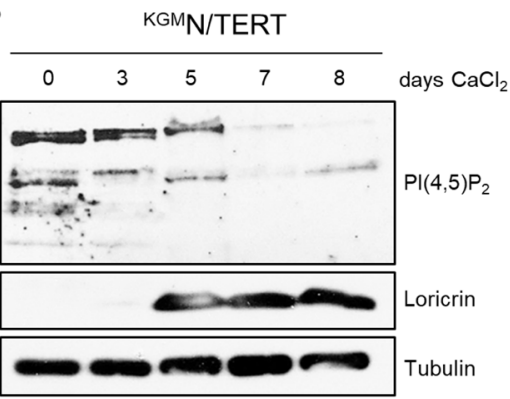

$E$

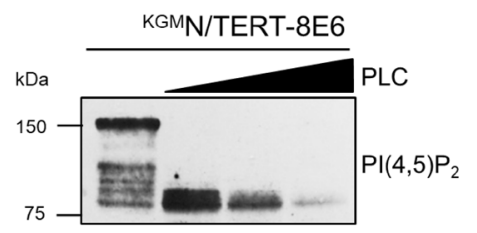

C

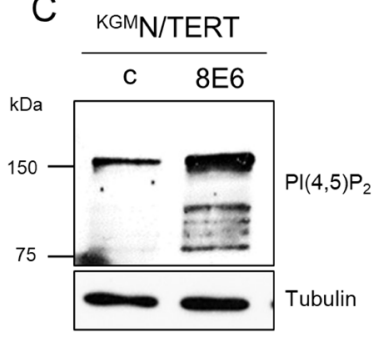

$\mathrm{F}$

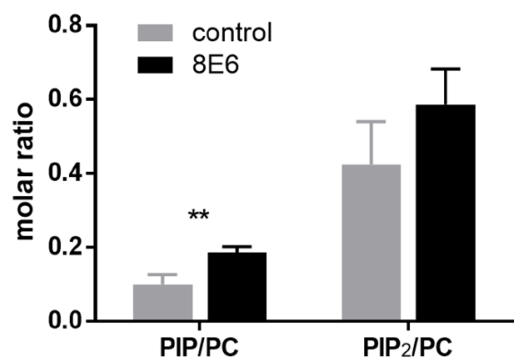

G

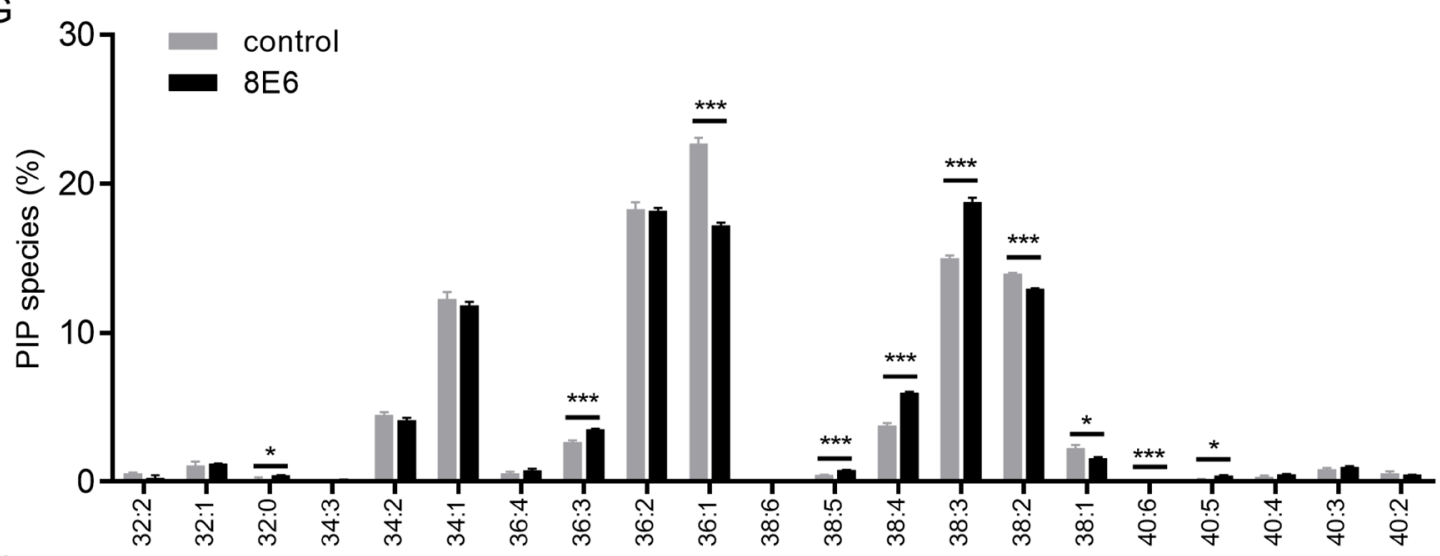

$\mathrm{H}$

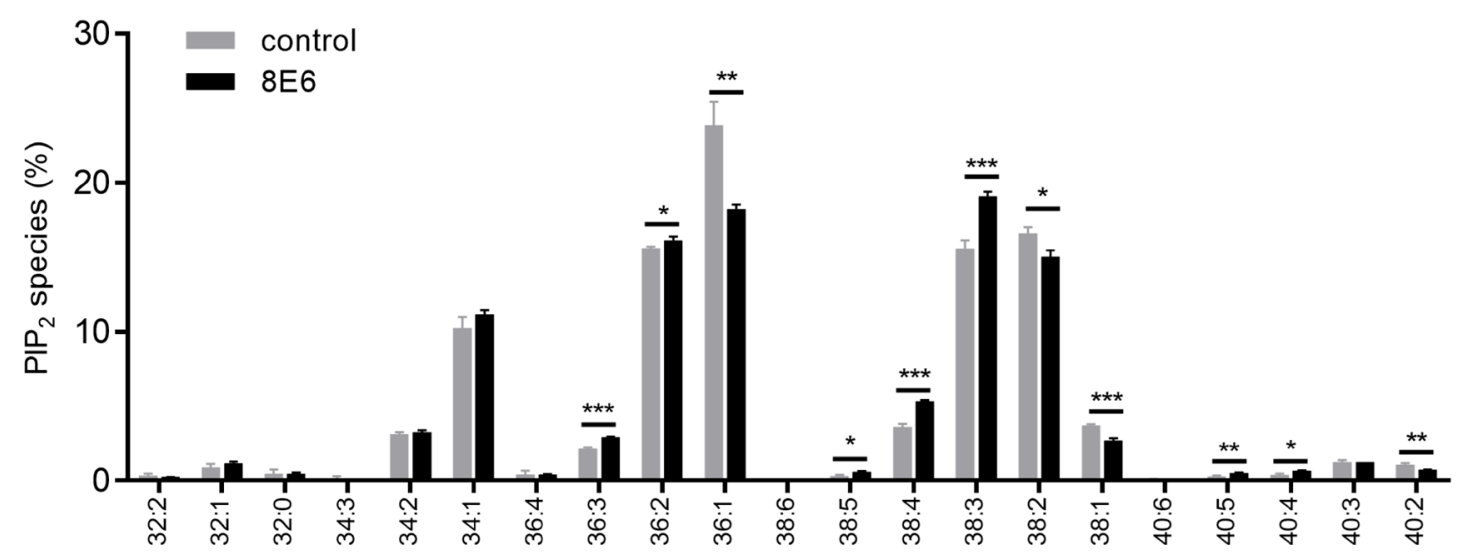

Figure 1: Expression of HPV8-E6 leads to high PI(4,5) $\mathrm{P}_{2}$ levels in N/TERTs cultured in low calcium media. (A) Representative Western blot for PI(4,5) $\mathrm{P}_{2}$ in total cell extracts of ${ }^{\mathrm{RM}+} \mathrm{N} / \mathrm{TERTs}$ and ${ }^{\mathrm{KGM}} \mathrm{N} / \mathrm{TERTs}$. Equal protein loading was confirmed by immunoblotting for Tubulin. (B) Representative Western blot for PI $(4,5) \mathrm{P}_{2}$ in total cell extracts of ${ }^{\mathrm{KGM}} \mathrm{N} / \mathrm{TERT}$ grown in low calcium and then switched to high calcium concentrations for up to 8 days. Calcium induced keratinocyte differentiation was confirmed by Western blotting for Loricrin. Equal protein loading was confirmed by immunoblotting for tubulin. (C) Representative Western blot for PI $(4,5)$ $\mathrm{P}_{2}$ in total cell extracts of empty vector positive ${ }^{\mathrm{KGM}} \mathrm{N} / \mathrm{TERT}-\mathrm{pLXSN}$ or ${ }^{\mathrm{KGM}} \mathrm{N} / \mathrm{TERT}-8 \mathrm{E} 6$. Difference in intensity of PI $(4,5) \mathrm{P}_{2}$ bands in 
${ }^{\mathrm{KGM} N}$ /TERTs between Figure 1A and 1D is due to $80 \mu \mathrm{g}$ total protein and long exposure of blot to film versus $40 \mu \mathrm{g}$ total protein and short exposure. Equal protein loading was confirmed by immunoblotting for tubulin. (D) Representative Western blot for PI(4,5) $\mathrm{P}_{2}$ in total cell extracts of ${ }^{\mathrm{KGM}} \mathrm{N} / \mathrm{TERT}-\mathrm{pLXSN}$ and ${ }^{\mathrm{KGM}} \mathrm{N} / \mathrm{TERT}-8 \mathrm{E} 6$ treated with skimmed milk containing either PI(4,5)P $\mathrm{P}_{2}$ specific antibodies (top) or in milk containing $100 \mathrm{mM}$ Neomycin (bottom). (E) Total cell extracts of ${ }^{\mathrm{KGM}} \mathrm{N} / \mathrm{TERT}-8 \mathrm{E} 6$ were treated with $0,5,10$ or $20 \mathrm{mU}$ Phospholipase C (PLC). (F) Quantification of phosphoinositide levels in HPV8-E6 expressing keratinocytes. Relative amounts of PIP and PIP 2 levels in ${ }^{\mathrm{KGM} N}$ /TERT-pLXSN and ${ }^{\mathrm{KGM} N / T E R T-8 E 6}$ cells. Bars present phosphoinositide values normalized to phosphatidylcholine (PC) levels $\left(\mathrm{PIP}_{\mathrm{x}} / \mathrm{PC}\right)$. Data are presented as mean $\pm \mathrm{SD}(n=3)$. $(\mathbf{G}-\mathbf{H})$ Effect of E6 expression on the relative distribution of PIP $(\mathbf{G})$ and PIP $2(\mathbf{H})$ molecular species. Lipid species are annotated based on their fatty acyl composition $\mathrm{x}: \mathrm{y}$, with $\mathrm{x}=$ total number of $\mathrm{C}$ atoms in both fatty acyl chains, and $y=$ total number of double bonds in both fatty acyl chains). Data are normalized to $100 \%$ within each lipid class and are displayed as mean $\pm \operatorname{SD}(n=3)$.

A
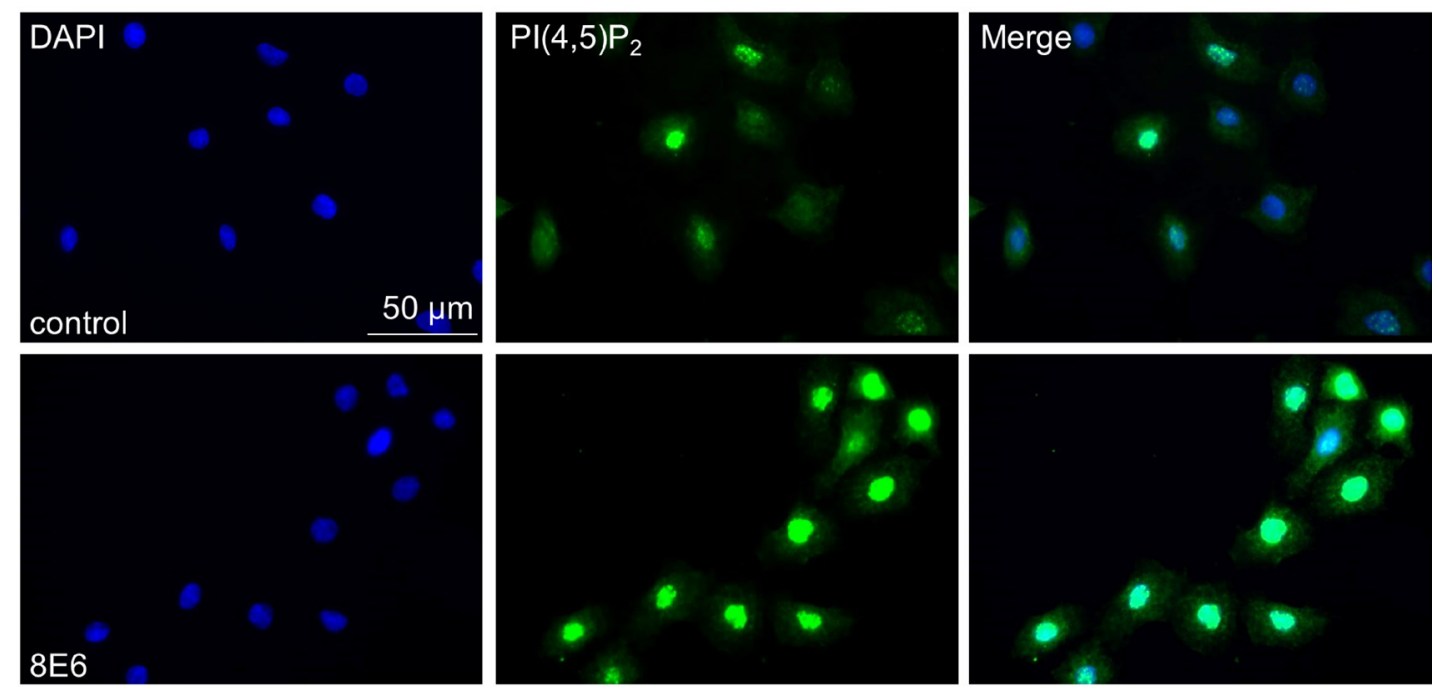

B
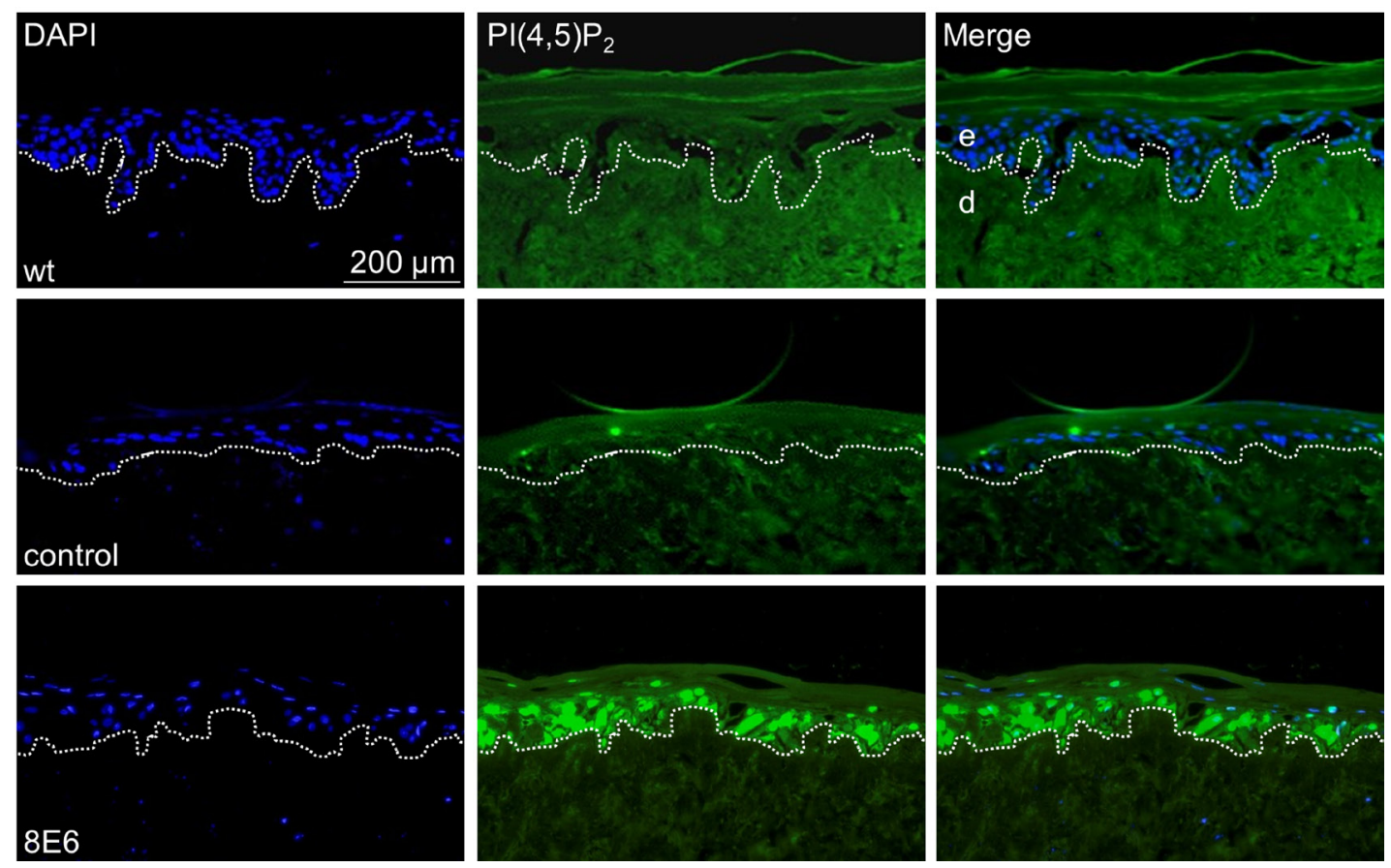

Figure 2: The nuclear PI(4,5) $\mathbf{P}_{2}$ pool is enriched in HPV8-E6 positive keratinocytes. (A) Representative immunocytochemical staining of $\mathrm{PI}(4,5) \mathrm{P}_{2}$ in ${ }^{\mathrm{KGM}} \mathrm{N} / \mathrm{TERT}-\mathrm{pLXSN}$ and ${ }^{\mathrm{KGM} N}$ /TERT-8E6 showing an increase in nuclear PI(4,5) $\mathrm{P}_{2}$ levels in HPV8-E6 positive cells (blue: DAPI; green: $\left.\mathrm{PI}(4,5) \mathrm{P}_{2}\right)$. (B) Representative immunofluorescence staining image of $\mathrm{PI}(4,5) \mathrm{P}_{2}$ on organotypic skin cultures based on de-epidermalized human dermis as matrix, which was repopulated with wt PHK or PHK coding for the empty retroviral vector pLXSN or pLXSN-8E6. The organotypic cultures were grown for 14 days at the air-liquid interphase, followed by fixing and embedding in paraffin. 
vector $\mathrm{pLXSN}$, and recombinant retroviruses were used to transduce ${ }^{\mathrm{KGM}} \mathrm{N} / \mathrm{TERTs}$. As shown in Figure $6 \mathrm{~B}$, ${ }_{\mathrm{KGM}} \mathrm{N} / \mathrm{TERTs}$ expressing the mutated proteins all showed elevated $\mathrm{PI}(4,5) \mathrm{P}_{2}$, thus providing evidence that targeting $\mathrm{PI}(4,5) \mathrm{P}_{2}$ is a specific strategy independent of HPV8-E6 disruption of NOTCH-mediated signaling.

\section{$\mathrm{PI}(4,5) \mathrm{P}_{2}$ metabolism is targeted by HPV8-E6}

In principle, $\mathrm{PI}(4,5) \mathrm{P}_{2}$ is synthesized by either phosphorylation of phosphatidylinositol-4-phosphate
(PI4P) by the lipid kinase phosphatidylinositol-4phosphate-5-kinase type I (PIP5KI) or by phosphorylation of phosphatidyl-inositol-5-phosphate (PI5P) by phosphatidyl-inositol-5-phosphate 4-kinase type II (PIP4KII) [33]. Each of these kinases has three isoforms, designated $\alpha, \beta$ and $\gamma$. Since the cellular levels of PI4P are much higher than those of PI5P, it is accepted that the majority of nuclear $\mathrm{PI}(4,5) \mathrm{P}_{2}$ is synthesized through PIP5KI [34]. To identify the kinase isoforms involved in $\mathrm{PI}(4,5) \mathrm{P}_{2}$ generation in $\mathrm{N} / \mathrm{TERT}$, we performed RT-qPCRs, and quantified the mRNA levels of all
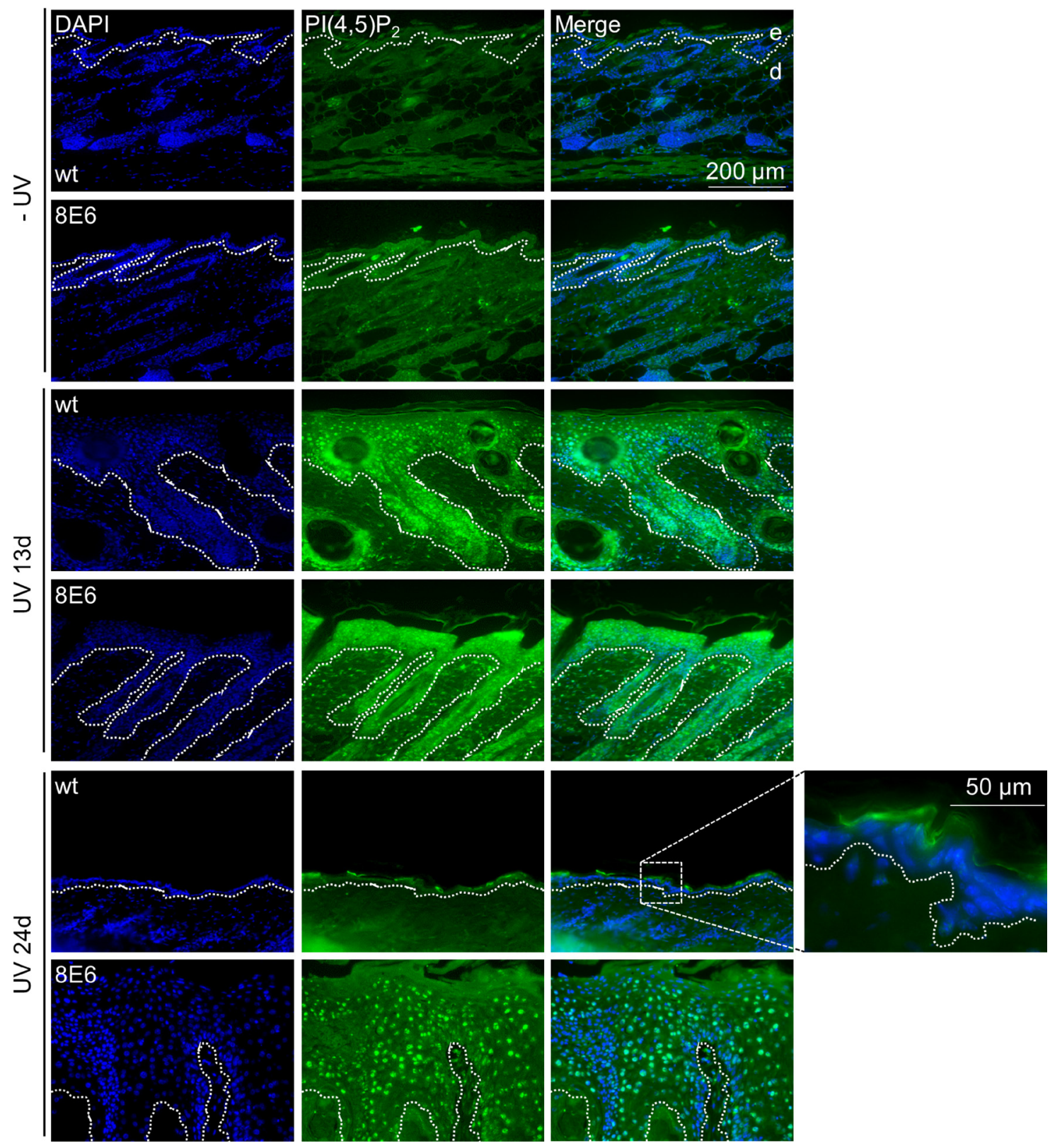

Figure 3: Skin tumors of K14-HPV8-E6 transgenic mice display elevated levels of PI(4,5) $\mathbf{P}_{2}$. Skin biopsies were taken from FVB/n-wt $(n=4)$ and K14-HPV8-E6 $(n=4)$ mice out of the UV irradiated skin area 13 days or 24 days following UV treatment. Additionally, skin biopsies were taken from non-irradiated $(n=4) \mathrm{FVB} / \mathrm{n}-\mathrm{wt}$ and K14-HPV8-E6 $(n=4)$ mice, respectively. Paraffin sections were stained for $\mathrm{PI}(4,5) \mathrm{P}_{2}$ (blue: DAPI; green: $\mathrm{PI}(4,5) \mathrm{P}_{2}$; dashed line: basement membrane zone; d: dermis; e: epidermis). The magnified image of wt skin 24 days following UV treatment demonstrates unspecific staining in the cornified cell layer. 


\section{A}
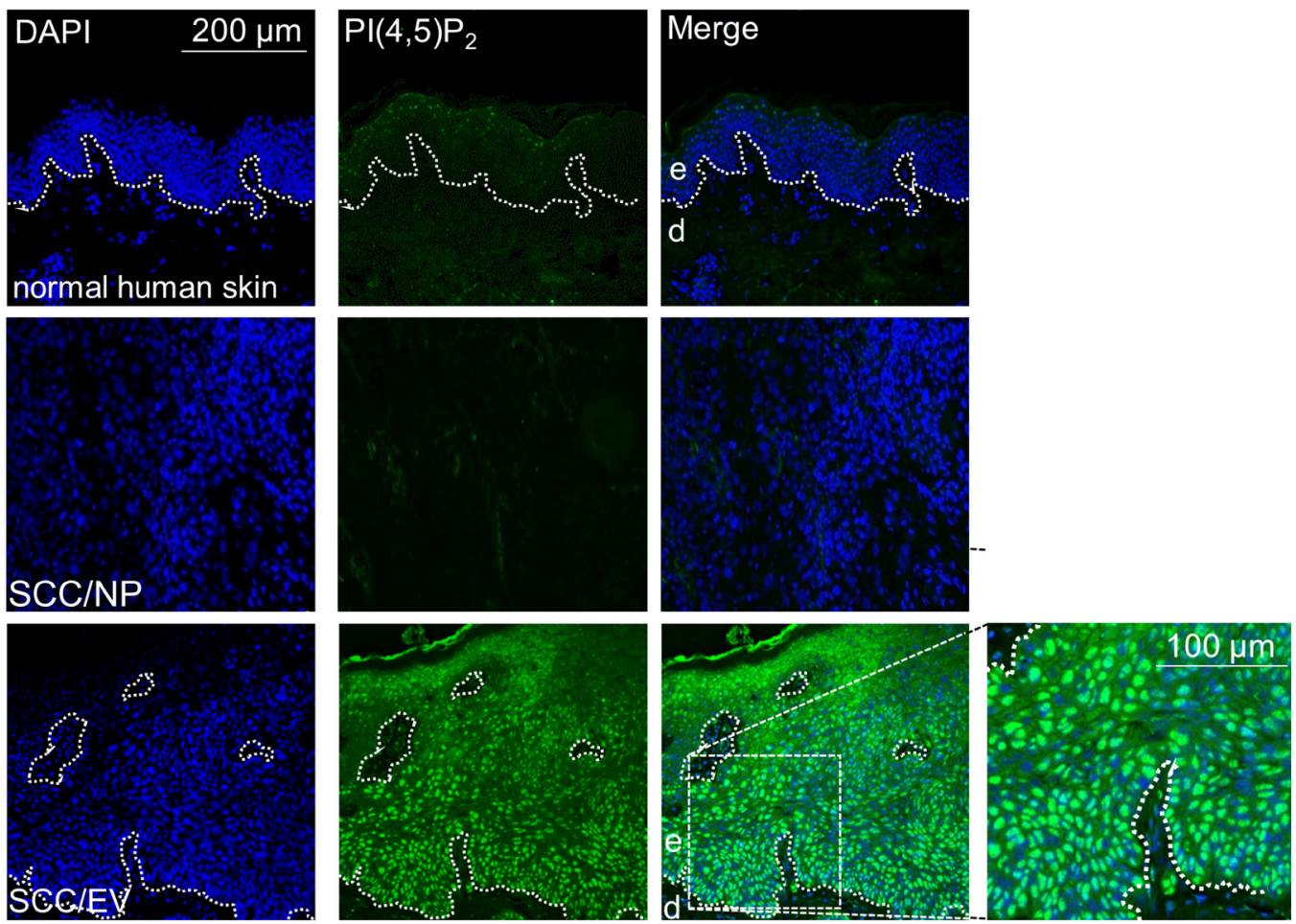

\section{$\mathrm{B}$}
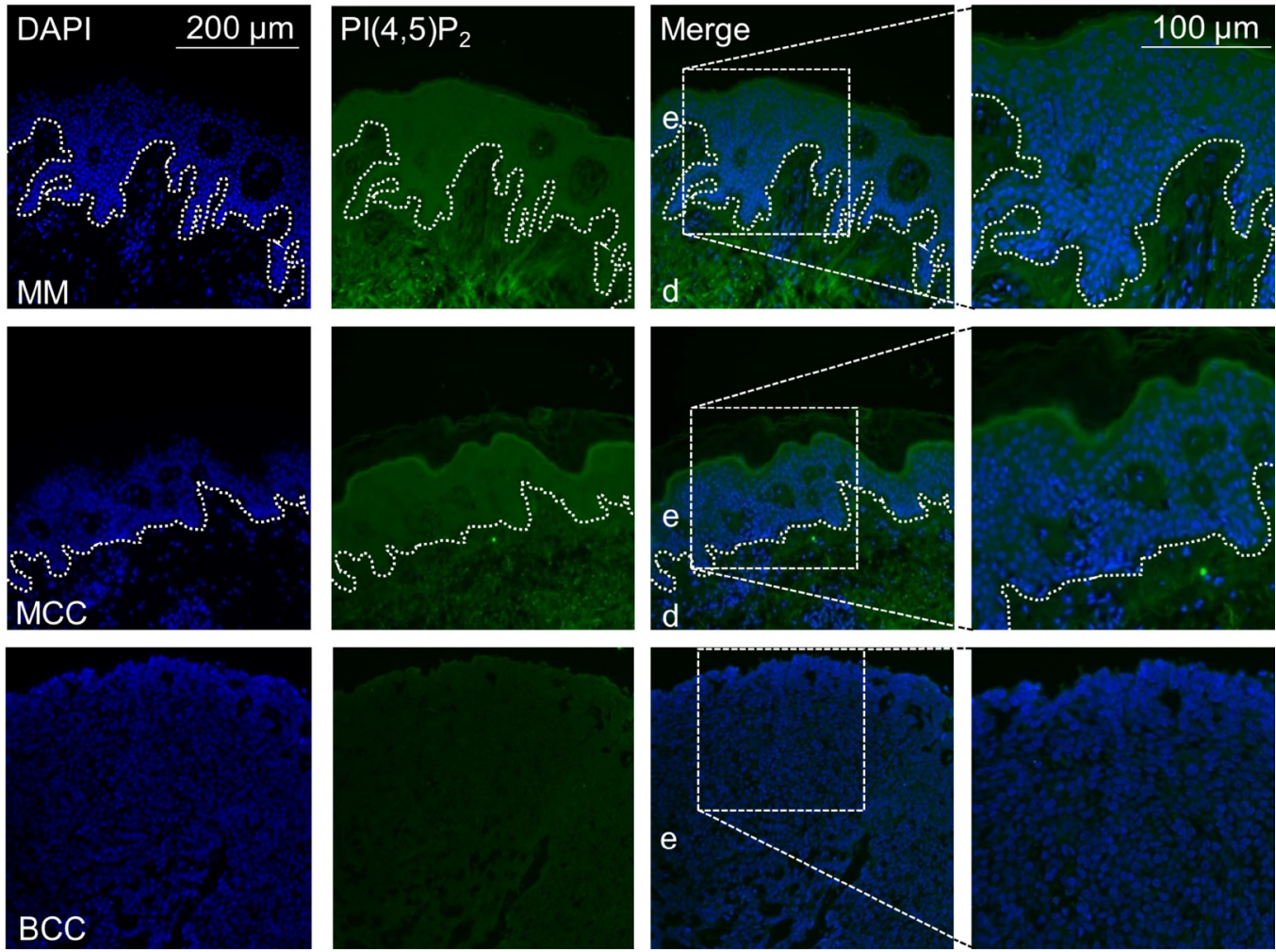

Figure 4: High nuclear PI(4,5) $\mathbf{P}_{2}$ levels in human keratinocyte skin cancer. (A) Representative immunofluorescence staining for PI(4,5) $\mathrm{P}_{2}$ in normal human skin, skin SCC of the normal population (SCC/NP) and HPV8 positive EV-SCC. Histology of the EV lesions is shown by HE staining (blue: DAPI; green: $\mathrm{PI}(4,5) \mathrm{P}_{2}$; dashed line: basement-membrane zone; d: dermis; e: epidermis). (B) Representative immunofluorescence staining for $\mathrm{PI}(4,5) \mathrm{P}_{2}$ in malignant melanoma (MM, $n=5$ ), Merkel cell polyomavirus positive Merkel cell carcinoma (MCC, $n=5$ ) and basal cell carcinoma (BCC, $n=5$ ) (blue: DAPI; green: PI(4,5) $\mathrm{P}_{2}$; dashed line: basement-membrane zone; d: dermis; e: epidermis). 
six kinases in ${ }^{\mathrm{KGM}} \mathrm{N} / \mathrm{TERTs}$ and ${ }^{\mathrm{RM}+} \mathrm{N} / \mathrm{TERTs}$. ${ }^{\mathrm{KGM}} \mathrm{N} /$ TERTs contained higher transcript levels for PIP4KII $\alpha$ (2-fold, $p=0.0078)$, PIP4KII $\beta$ (1.7, $p<0.0001)$, PIP4KII $\gamma$ (2-fold, $p=0.0004)$, and PIP5KI $\gamma$ (1.5-fold, $p=0.0003)$. PIP5KI $\alpha$ did not show a significant difference in mRNA expression (Figure 7A). Expression of HPV8-E6 led to a significant upregulation of PIP4KII $\alpha$ of about 1.7fold ( $p=0,0026)$, a 2.2-fold upregulation of PIP4KII $\beta$ $(p=0,0356)$, a 3.7-fold upregulation of PIP4KII $\gamma$ $(p=0,0049)$, a 1,7-fold upregulation of PIP5KI $\alpha$ $(p=0,0037)$ and a 2-fold upregulation of PIP5KI $\gamma$ $(p=0,0026)$ (Figure 7B). To identify the kinase isoform mainly contributing to the synthesis of $\mathrm{PI}(4,5) \mathrm{P}_{2}$, PIP4KII $\alpha$, PIP4KII $\beta$, PIP5KI $\alpha$ and PIP5KI $\gamma$ were individually silenced by using siRNA pools. Although a strong knock-down could be achieved for all four tested kinases, no significant changes of $\mathrm{PI}(4,5) \mathrm{P}_{2}$ bound protein bands were observed in Western blots (Supplementary Figure 1).
With the aim to determine whether HPV8-E6 may directly interact with intracellular proteins involved in $\mathrm{PI}(4,5) \mathrm{P}_{2}$ regulation, we next performed immunoprecipitation-coupled mass spectroscopy and thus identified the inositol-polyphosphate-5-phosphatase (OCRL1) as a potential interaction partner of E6 which is known to have substrate specificity for $\mathrm{PI}(4,5) \mathrm{P}_{2}$ and $\mathrm{PI}(3,4,5) \mathrm{P}_{3}[35]$. The subsequent Co-IP analysis confirmed OCRL1 as a newly identified HPV8-E6 interacting phosphatase (Figure 7C).

Additionally, we addressed the question whether there may be direct phospholipid-binding of E6. We therefore transfected keratinocytes with a plasmid encoding for a FlagHPV8-E6 fusion protein and subsequently generated total cell extracts and used these extracts to test the E6 binding capacity to phospholipids in a protein-lipid overlay assay on PIP-Strips. Intriguingly, this overlay assay, developed with an anti-Flag antibody, revealed binding specificity of E6 to phosphatidylinositol (PI), whereas cross-reactivity

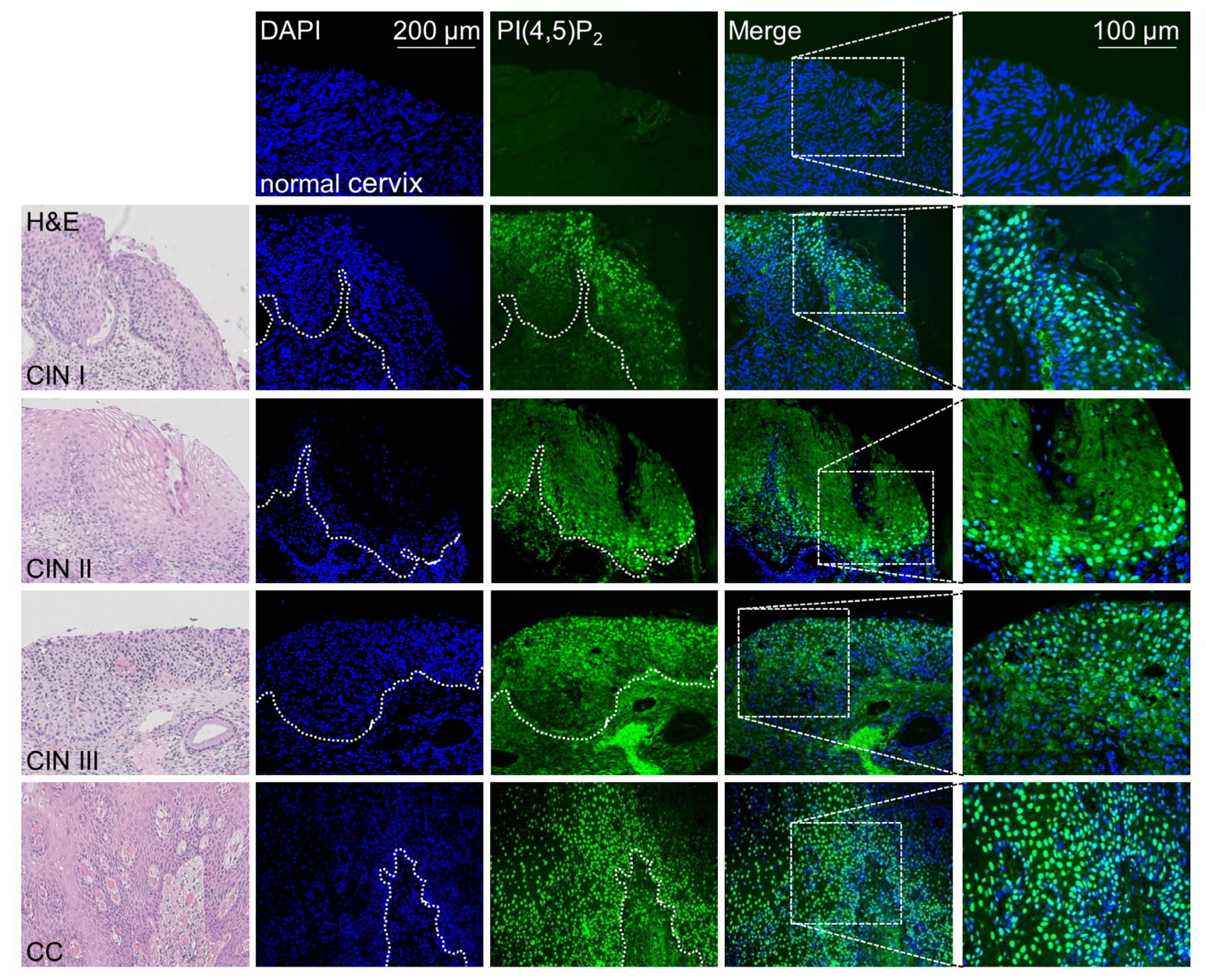

Figure 5: Enhanced nuclear PI(4,5)P, levels in HPV16 positive cervical tumors. Representative immunofluorescence staining for PI(4,5) $\mathrm{P}_{2}$ in normal cervix $(n=3)$, and HPV16 positive CIN I $(n=3)$, CIN II $(n=5)$, CIN III $(n=11)$ and cervical cancer $(\mathrm{CC}, n=3)$ (blue: DAPI; green: $\left.\mathrm{PI}(4,5) \mathrm{P}_{2}\right)$. Histology of the tissue is shown in the HE staining images. 
with various phospholipids, including $\mathrm{PI}(4,5) \mathrm{P}_{2}$ and other phosphoinositides was negligibly small (Figure 7D).

In summary, as schematically outlined in Figure 7E, our results provide new mechanistic insights identifying the $\mathrm{PI}(4,5) \mathrm{P}_{2}$ metabolic pathway as new target of HPV8-E6.

\section{CAND1 and SND1 are phospholipidized in HPV8-E6 positive keratinocytes}

In order to identify the $\mathrm{PI}(4,5) \mathrm{P}_{2}$ bound proteins in

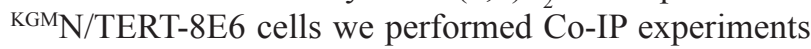
using the anti-PI(4,5) $\mathrm{P}_{2}$ antibody with subsequent mass spectrometric analysis. The comparative proteomic profiling of total E6 cell extracts compared with wildtype keratinocytes revealed 10 nuclear proteins with a molecular mass between $75-150 \mathrm{kDa}$ by at least 2 unique peptides in both control and E6 positive cells (Supplementary Table 1). To verify these findings, both Co-IP and siRNA-knockdown experiments were carried out, which identified CAND1 (Cullin-associated NEDD8dissociated protein-1) and SND1 (Staphylococcal nuclease domain-containing protein 1) as nuclear proteins differentially phospholipidized in the presence of E6. While total levels of CAND1 and SND1 were not significantly changed, immunoprecipitates of CAND1 and SND1 were found to be bound to $\mathrm{PI}(4,5) \mathrm{P}_{2}$ in ${ }^{\mathrm{KGMN}}$ / TERT-8E6, but not ${ }^{\mathrm{KGM} N / T E R T-p L X S N}$ cells (Figure 8).

\section{DISCUSSION}

Phosphoinositides have proven to be key lipid messengers regulating almost every singular aspect of eukaryotic cell physiology [36]. Among them, PI(4,5) $\mathrm{P}_{2}$ has been demonstrated to play a key role in generating other phosphoinositide species as well as other lipid messengers [37]. $\mathrm{PI}(4,5) \mathrm{P}_{2}$ directly interacts with a vast range of proteins called $\mathrm{PI}(4,5) \mathrm{P}_{2}$ effectors. Its concentration is dramatically altered by external or internal stimuli to efficiently regulate intracellular functions [25, 26], a mechanism we have now proven to be hijacked by the HPV8-E6 oncoprotein. Furthermore, nuclear, nonmembrane pools of signaling phosphoinositides have previously been shown to be crucial for carcinogenesis [18]. Our initial observation, that $\mathrm{PI}(4,5) \mathrm{P}_{2}$ associated protein bands were found in ${ }^{\mathrm{KGM}} \mathrm{N} / \mathrm{TERT}$ comparing them to ${ }^{\mathrm{RM}+} \mathrm{N} / \mathrm{TERTs}$, combined with a decrease of $\mathrm{PI}(4,5) \mathrm{P}_{2}$ signals following calcium induced differentiation of ${ }^{K G M} \mathrm{~N} / \mathrm{TERTs}$ provides even more compelling evidence that accumulation of $\mathrm{PI}(4,5) \mathrm{P}_{2}$ is taking place in nondifferentiated keratinocytes. The fact that $\mathrm{PI}(4,5) \mathrm{P}_{2}$ bound protein signals and total levels of phosphoinositides were observed to be enhanced in the presence of HPV8-E6 further underpins the potential role of $\mathrm{PI}(4,5) \mathrm{P}_{2}$ in maintenance of an undifferentiated cell phenotype. The shift towards polyunsaturated lipid species $38: 4$ and 38:3, which are mainly comprised of 18:0/20:4 and 18:0/20:3, further suggests that these lipids may contribute to HPV8-E6 induced cell transformation.

The highly significant $\mathrm{PI}(4,5) \mathrm{P}_{2}$ signals in skin hyperplasia following UV treatment in wt mice and K14HPV8-E6 transgenic mice, combined with the observation of a reduction of $\mathrm{PI}(4,5) \mathrm{P}_{2}$ to undetectable levels upon skin healing in wt mouse. Satz unvollständig, support a crucial role of $\mathrm{PI}(4,5) \mathrm{P}_{2}$ in epidermal wound healing, and re-establishment of skin homeostasis following UV irradiation. Activated keratinocytes driving re-epithelialization may fail to switch off their activated status upon wound-healing in HPV infected skin [4]. Collectively, this may result in constantly elevated nuclear $\mathrm{PI}(4,5) \mathrm{P}_{2}$ levels, with profound promoting effects on
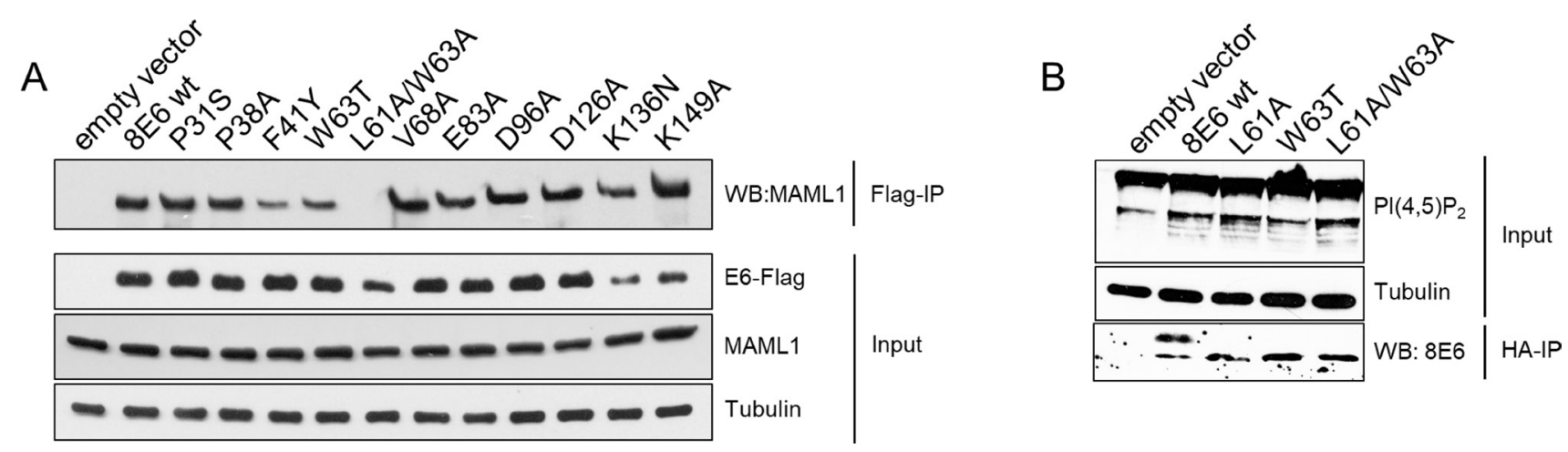

Figure 6: Increase of PI(4,5) $\mathrm{P}_{2}$ in E6 cells is independent of the E6 capability to bind to MAML1. (A) Extracts from C33a cells, transiently transfected with either empty vectors or plasmids coding for Flag-8E6-wt, -P31S, -P38S, -F41Y, -W63T, -L61A/W63A, -V68A, -E83A, -D96A, -D126A, -K136N, -K149A were incubated with M2-FLAG-agarose. Co-immunoprecipitated of MAML1 and 10\% of the input extracts were subjected to Western blots with specific antibodies. Expression of HPV8-E6 was confirmed by a Western blot for the Flag-tagged HPV8-E6 protein. Equal protein loading was confirmed by immunoblotting for tubulin. (B) N/TERTs were transduced with retroviruses encoding for either the empty vector pLXSN-HA or HA-tagged HPV8-E6wt, -L61A, -W63T or L61A/W63A. PI(4,5)P, was detected with specific antibodies. Expression of HPV8-E6 was confirmed by Co-IP of the HA-tagged proteins. Equal protein loading was confirmed by immunoblotting for tubulin. 
A

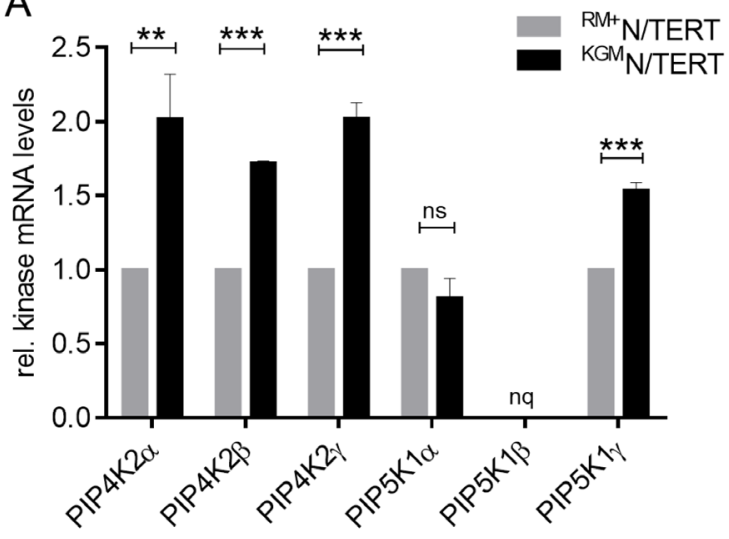

C

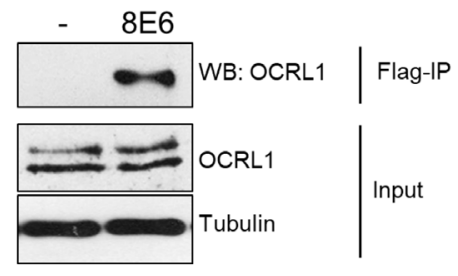

B

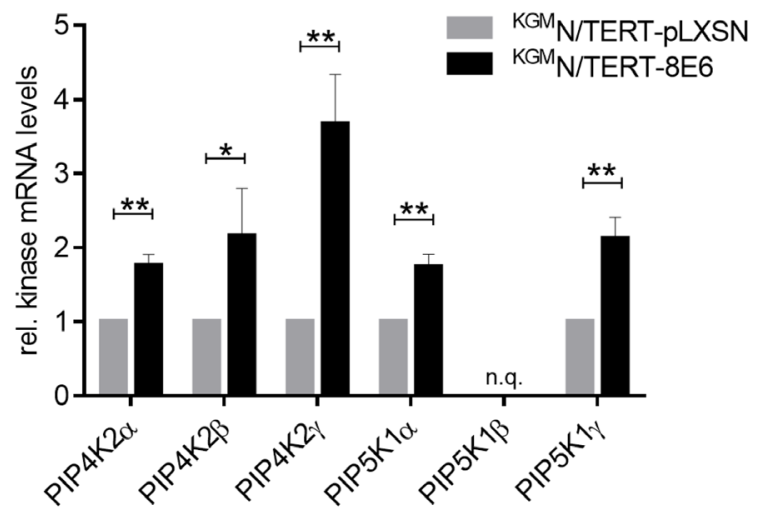

D

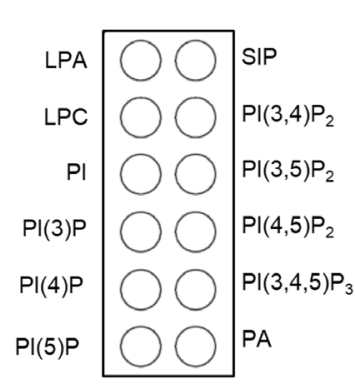

Flag-8E6

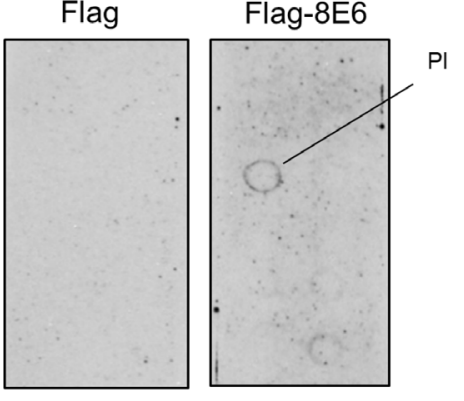

ab: anti-Flag

$E$
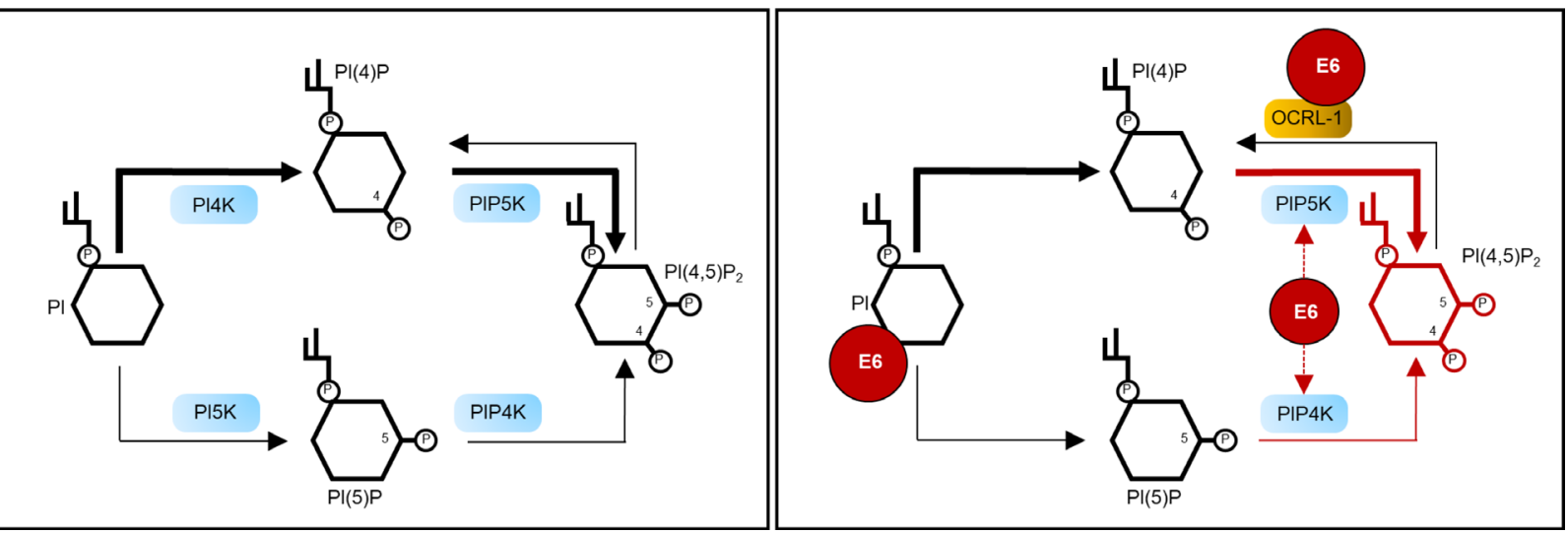

Figure 7: HPV8-E6 interferes with kinases and the phosphatase regulating PI(4,5) $\mathrm{P}_{2}$ levels. (A) Quantification of PIP4KII $\alpha$, $\beta, \gamma$ and PIP5KI $\alpha, \beta, \gamma$ mRNA expression by RT-qPCR in ${ }^{\mathrm{KGM}} \mathrm{N} / \mathrm{TERTS}$ and ${ }^{\mathrm{RM}+} \mathrm{N} / \mathrm{TERTs}(n=3$ independent experiments measured in duplicates). Data were normalized to the HPRT1 mRNA levels and are presented as mean \pm SEM. The relative gene expression level of ${ }^{\mathrm{RM}+} \mathrm{N} / \mathrm{TERTS}$ was set as $1{ }^{* *} p<0.01 ;{ }^{* * *} p<0.001$; nq: not quantifiable; ns: not significant). (B) Quantification of PIP4KII $\alpha, \beta, \gamma$ and PIP5KI $\alpha, \beta, \gamma$ mRNA expression by RT-qPCR in ${ }^{\mathrm{KGM}} \mathrm{N} / \mathrm{TERT}$-pLXSN and ${ }^{\mathrm{KGM}} \mathrm{N} / \mathrm{TERT}-8 \mathrm{E} 6(n=3$ independent experiments measured in duplicates). Data were normalized to HPRT1 mRNA levels and are presented as mean \pm SEM. The relative gene expression level of ${ }^{\mathrm{KGM} N}$ /TERT-pLXSN was set as $1\left({ }^{*} p<0.05 ;{ }^{* *} p<0.01\right.$; nq: not quantifiable). (C) Extracts from C33a cells, transiently transfected with expression vectors for empty vector or Flag-HPV8-E6wt were incubated with M2-FLAG-agarose. Co-immunoprecipitated OCRL-1 and $10 \%$ of the input extracts were detected by Western blot with specific antibodies $(n=5)$. The expression of HPV8-E6 was confirmed by a Western blot against the Flag tag. Equal protein loading was confirmed by immunoblotting for tubulin. (D) Schematic diagram of the nitrocellulose membrane with immobilized phospholipids in 100 picomole spots (PIP-strip; left image); LPA: lysophosphatidic acid; LPC: lysophosphocholine; PI: phosphatidylinositol; SIP: sphingosine-1-phosphate; PA: phosphatidic acid. Representative images of PIP-strips incubated with total cell extracts of C33a cells transiently transfected with pXJ41-Flag (middle image) or pXJ41-8E6-Flag (right image). Membranes were washed and lipid-bound Flag-8E6 was detected with monoclonal anti-Flag antibody. (E) The left image shows the PI $(4,5) \mathrm{P}_{2}$ pathway flow in a normal keratinocyte. The right image schematically summarizes HPV8-E6 targets involved in PI $(4,5) \mathrm{P}_{2}$ metabolism. The figure also shows that the PIP5K pathway is the major and PIP4K the minor route of $\mathrm{PI}(4,5) \mathrm{P}_{2}$ synthesis. 
both initiation and growth of HPV positive skin tumors. The nuclear staining pattern of $\mathrm{PI}(4,5) \mathrm{P}_{2}$ in EV skin lesions (with high betaPV loads) and absence of $\mathrm{PI}(4,5) \mathrm{P}_{2}$ in $\mathrm{SCC}$ with low betaPV loads, basal cell carcinoma, melanoma or Merkel cell carcinoma may imply a role of $\mathrm{PI}(4,5) \mathrm{P}_{2}$ signaling in betaPV dependent skin carcinogenesis. The observation that high betaPV loads correlated with high $\mathrm{PI}(4,5) \mathrm{P}_{2}$ levels underpins the importance of $\mathrm{PI}(4,5) \mathrm{P}_{2}$ in betaPV mediated skin SCC development.

As the E6 mutant W61A/W63A was unable to form a complex with MAML1 but still led to an increase of PI(4,5) $\mathrm{P}_{2}$, we provide evidence that an E6 mediated increase of $\mathrm{PI}(4,5) \mathrm{P}_{2}$ is independent of its ability to interfere with the MAML1/NOTCH signaling pathway. In a recent study, seeking to define key amino acids in E6 relevant for MAML1 binding, the authors identified the residue K64 as also being crucial for MAML1 binding, indicating the importance of amino acids around position 61-64 [11]. Taken together, the elevated levels of nuclear PI(4,5) $\mathrm{P}_{2}$ in HPV8 and HPV16 positive patient tissues suggest a high significance of our findings for keratinocyte cancer development and may thus be relevant for novel cancer therapy concepts by targeting nuclear $\mathrm{PI}(4,5) \mathrm{P}_{2}$-driven tumor growth.

We next asked, which $\mathrm{PI}(4,5) \mathrm{P}_{2}$ metabolic enzymes may contribute to $\mathrm{PI}(4,5) \mathrm{P}_{2}$ accumulation. Although PIP4KII and PIP5KI synthesize the same end product, they are not functionally redundant [38]. Since the cellular levels of PI4P are much higher than those of PI5P, it seems likely that the majority of nuclear $\mathrm{PI}(4,5) \mathrm{P}_{2}$ is synthesized through PIP5KI [34]. The increase of PI $(4,5) \mathrm{P}_{2}$ signals

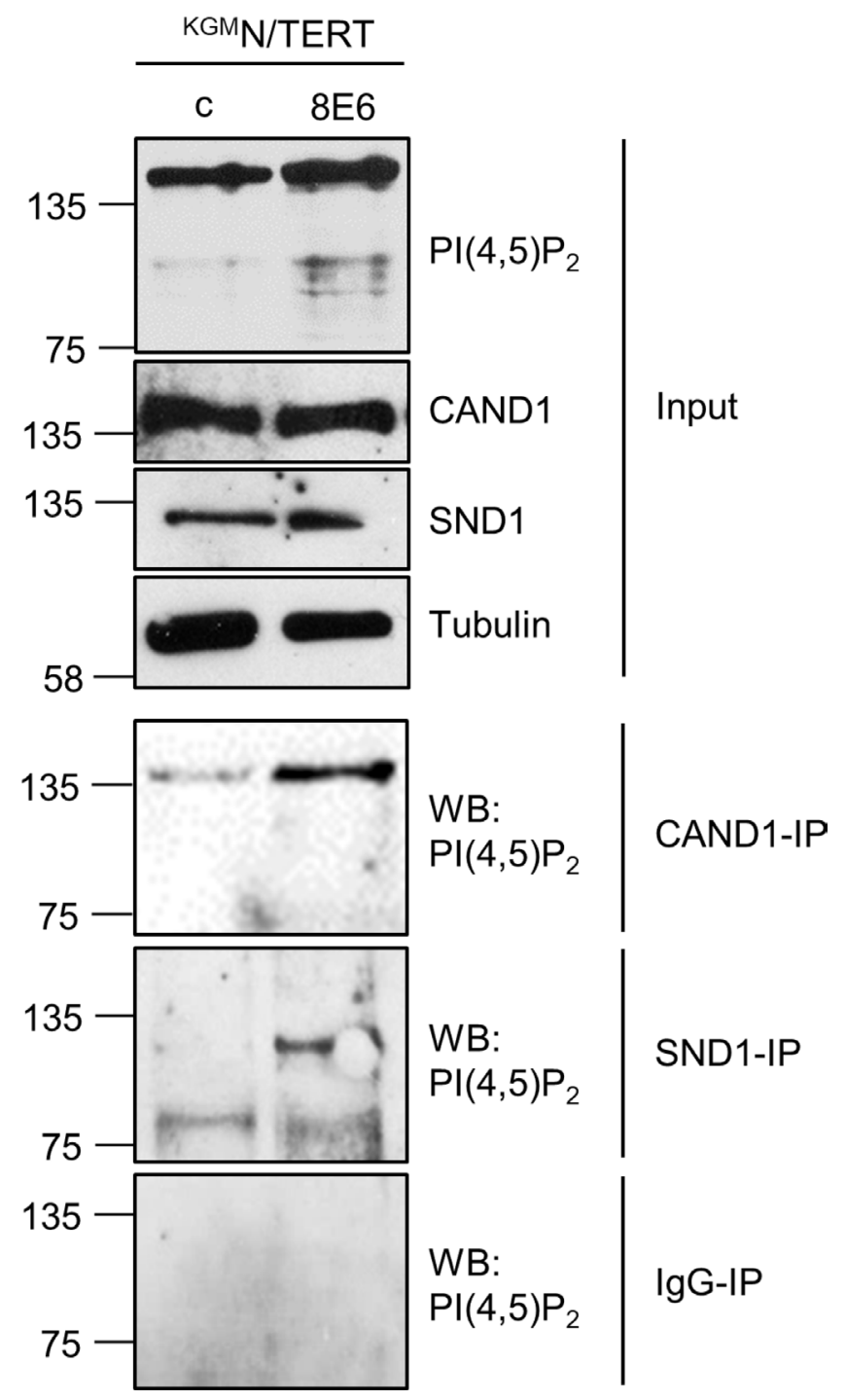

Figure 8: Identification of CAND1 and SND1 as PI(4,5) $\mathbf{P}_{2}$ binding cellular proteins. Extracts from ${ }^{K G M N}$ /TERT-pLXSN and ${ }^{\mathrm{KGM}} \mathrm{N} / \mathrm{TERT}-8 \mathrm{E} 6$ were incubated with A/G-agarose coupled with either CAND1, SND1 or normal IgG-mouse antibodies. Coimmunopecipitated $\mathrm{PI}(4,5) \mathrm{P}_{2}$ and $10 \%$ of the input extracts were detected by Western blot with specific antibodies against $\mathrm{PI}(4,5) \mathrm{P}_{2}$. Total levels of PI(4,5) $\mathrm{P}_{2}$, CAND1 and SND1 were detected using specific antibodies. Equal protein loading was confirmed by immunoblotting for tubulin. 
in ${ }^{\mathrm{KGM} N}$ /TERT-8E6 cells is associated with an increase in gene expression of these kinase isoforms. Combined with the fact that knockdown of a single isoform did not affect $\mathrm{PI}(4,5) \mathrm{P}_{2}$ levels led to the overall conclusion that several kinases are simultaneously contributing to nuclear $\mathrm{PI}(4,5) \mathrm{P}_{2}$ production. Whether E6 binding to OCRL1 may inactivate its phosphatase function and thereby contributes to the persistent high levels of $\mathrm{PI}(4,5) \mathrm{P}_{2}$ needs to be determined in future experiments. In addition, we could also show that HPV8-E6 binds PI, which suggests the intriguing possibility that HPV8-E6 may contain a phosphoinositide-binding domain. The interaction of E6 with PI may enforce phosphorylation of PI leading to the generation of the $\mathrm{PI}(4,5) \mathrm{P}_{2}$ precursors PI4P and PI5P. We therefore conclude, that all three processes could be relevant mechanisms involved in $\mathrm{PI}(4,5) \mathrm{P}_{2}$ metabolism.

Deregulation of the phosphoinositide signaling axis is associated with cancer development [39]. To assess possible consequences of the $\mathrm{PI}(4,5) \mathrm{P}_{2}$ metabolic pathway in betaPV associated skin cancer development, it should be noted that UV radiation - the major risk factor for skin cancer - usually causes $\mathrm{PI}(4,5) \mathrm{P}_{2}$ depletion during apoptosis independently of and prior to caspase activation [40, 41]. In addition, downregulation of PIP4KII and subsequent reduction of $\mathrm{PI}(4,5) \mathrm{P}_{2}$ triggers apoptosis in MDA-MB-231 breast cancer and Cos7 cells [42]. Regarding the co-factorial role of high betaPV loads in skin cancer development, the virus may counteract these pro-apoptotic signals through upregulation of $\mathrm{PI}(4,5) \mathrm{P}_{2}$.

Until now, only few nuclear $\mathrm{PI}(4,5) \mathrm{P}_{2}$ effector proteins have been identified and their functional classification pointed to roles in mRNA transcription regulation, mRNA splicing and protein folding [21]. By screening for potential $\mathrm{PI}(4,5) \mathrm{P}_{2}$ phospholipidized nuclear proteins in HPV8-E6 positive cells, the multifunctional regulator proteins CAND1 and SND1, which are known to be direct interaction partners $[43,44]$ were identified. CAND1 is a F-box exchange factor required for loading substrates onto the Cullin-Ring-ubiquitin ligase complex required for ubiquitination and proteasomal degradation of numerous protein substrates [45]. SND1 is known to be critically involved in virtually all pathways of gene expression, ranging from transcription to RNA silencing exerting a biochemical function as both a scaffolding molecule and/or a nuclease. SND1 is indispensable for normal development and stress resistance, whereas its deregulation is closely associated with various types of cancer [46, 47]. SND1 is higher expressed in basal as well as hair follicle keratinocytes than in terminally differentiated cells of the human interfollicular epidermis [48]. HPV induced phospholipidation of SND1 in keratinocytes may therefore contribute to HPV-mediated skin tumorigenesis. Since CAND1 and SND1 total protein levels were not changed upon HPV8-E6 expression, the observed rise in CAND1- and SND1-associated PI(4,5) $\mathrm{P}_{2}$ signals may result from enhanced phospholipidation. Our findings suggest that the CAND1-SND1 pathway may be an important regulatory node for HPV early gene functions, which will be subjects of further mechanistical studies.

In conclusion, we identified the $\mathrm{PI}(4,5) \mathrm{P}_{2}$ metabolism as a novel target of oncogenic HPV induced carcinogenesis. Further studies will be needed to expand our understanding of the exact biological and oncogenic implications, which may pave the way for entirely novel scientific avenues in the fields of HPV-mediated carcinogenesis.

\section{MATERIALS AND METHODS}

\section{Cell lines and treatments}

Isogenic N/TERTs (kindly provided by James Rheinwald, Harvard Medical School, Boston, MA, USA) [29] were either cultivated in KGM-Gold ( ${ }^{\mathrm{KGM}} \mathrm{N} / \mathrm{TERTs}$, Lonza, Cologne, Germany; containing low (0.05 mM) Calcium) or in $\mathrm{RM}+$ media $\left({ }^{\mathrm{RM}+} \mathrm{N} / \mathrm{TERT}\right)$ [49]. Differentiation of ${ }^{\mathrm{KGM}} \mathrm{N} / \mathrm{TERTs}$ was accomplished by treatment with $2 \mathrm{mM} \mathrm{CaCl}_{2}$ for up to 8 days. Retroviral transduction of N/TERTs was performed using the retroviral vector $\mathrm{pLXSN-HPV8-E6} \mathrm{as} \mathrm{previously} \mathrm{described}$ [50]. The generation of organotypic skin cultures of HPV8-E6 expressing PHK has been described elsewhere [51]. The HPV negative cervical carcinoma cell line C33a (purchased from American type Culture Collection (ATCC \#HTB-31)) was grown in Dulbecco's modified Eagle medium (DMEM, Life Technologies, Darmstadt, Germany), supplemented with 10\% fetal calf serum (FCS).

For the protein-lipid overlay assay on PIP-Strips (Echelon Biosciences), C33a cells were transiently transfected in 6-wells by the $\mathrm{CaCl}_{2}$-method with the empty eukaryotic expression vector pXJ41-Flag or pXJ418E6-Flag (kindly provided by Dr. G. Steger, Institute of Virology, University of Cologne, Germany) coding for Flag-tagged HPV8-E6. Total cell extracts were generated $48 \mathrm{~h}$ post transfection using low salt dilution buffer (LSDB) (50 mM Tris/HCl (pH 8), $20 \%$ Glycerol, 100 $\mathrm{mM} \mathrm{KCl,} \mathrm{0,1 \%} \mathrm{NP40,} 1$ mM DTT, $50 \mathrm{mM} \mathrm{NaF,} 1 \mathrm{mM}$ orthovanadate, $1 \mathrm{mM}$ PMSF, supplemented with $1 \times$ Cocktail Protease Inhibitors (Roche Diagnostics, Mannheim, Germany)). PIP-Strips were developed by incubation with cell extracts and an anti-Flag antibody. N/TERTs and C33a cells were authenticated by the Leibniz-Institute (DSMZGerman Collection of Microorganisms and Cell Cultures).

\section{Western blotting and co-immunoprecipitation}

For Western blot analysis, cells were trypsinized, pelleted by centrifugation and lysed on ice in LSDB buffer. The extracts were sonicated, and protein concentrations were determined using the Bio-Rad Protein Assay (Bio-Rad, Munich, Germany). Cell 
extracts were resolved by SDS-PAGE and transferred to a nitrocellulose membrane. After the membrane had been blocked with $5 \%$ skimmed milk in TBST (10 mM Tris/ $\mathrm{HCl}$ ( $\mathrm{pH} 8.0), 150 \mathrm{mM} \mathrm{NaCl}, 0.05 \%$ Tween 20) for $1 \mathrm{~h}$, the blots were probed with antibodies to Loricrin (ab24722, Abcam, Cambridge, UK), PI(4,5)P $\mathrm{P}_{2}$ (clone 2C11, Santa Cruz, Heidelberg, Germany) [30] and tubulin (clone YL1/2, Abcam), which was used as loading control. Immunoreactive proteins were visualized using horse-reddish-peroxidase coupled secondary antibodies and BM Chemiluminescence Blotting Substrate (Roche Diagnostic). For Co-IP experiments, cell extracts of transiently transfected $\mathrm{C} 33 \mathrm{a}$ were incubated with antibody coupled agarose for $2 \mathrm{~h}$ at $4^{\circ} \mathrm{C}$, followed by three washes with LSDB containing different $\mathrm{KCl}$ concentrations. Coprecipitated cellular proteins were detected by Western blotting. The antibodies used for these studies were: anti-HA (3F10, Roche Diagnostics), anti-Flag (clone M5, Sigma), anti-OCRL-1 (8797, Cell Signaling), antiMAML1 (D3K7B, Cell Signaling), anti-CAND1 (G-3, Santa Cruz), anti-SND1 (F-5, Santa Cruz).

\section{Quantitative PCR following reverse transcription (RT-qPCR)}

Total RNA was isolated from cells using the RNeasy kit, and DNase digestion was performed on a column using RNase-free DNase according to the manufacturer's instructions (Qiagen, Hilden, Germany). One microgram of total RNA was reverse transcribed using the Omniscript RT kit (Qiagen) with $10 \mu \mathrm{M}$ random nonamers (TIB MOLBIOL, Berlin, Germany) and $1 \mu \mathrm{M}$ oligo $\left(\mathrm{dT}_{23}\right)$ primer (Sigma), as well as 10 units of RNase inhibitor (Fermentas, St. Leon-Rot, Germany). Quantitative PCR (qPCR) was performed using the Light-Cycler system (Roche). Amplified PCR fragments were cloned into pJET1.2 (Qiagen) to generate absolute standards with primers also used for subsequent qPCR analysis. Samples were analyzed in duplicate together with a 10-fold dilution series of standard plasmids. The mRNA expression levels of target genes were normalized to the mRNA levels of hypoxanthine phosphoribosyltransferase 1 (HPRT1). The primers used in this study had the following 5'-to-3' sequences:

HPRT1-fw: CCTAAGATGAGCGCAAGTTGAA, HPRT1-bw: CCACAGGACTAGAACACCTGCTAA; PIP4KII $\alpha$-fw: ATGGAATTAAGTGCCATGAAAAC PIP4KII $\alpha$-bw: GCATCATAATGAGTAAGGATGTCAAT PIP4KIIß-fw: TGCATGTGGGAGAGGAGAGT PIP4KII $\beta$-bw: TCAGCTGTGCCAAGAACTCA PIP4KII $\gamma$-fw: GTGTTCCTGTGGGGCGTA PIP4KII $\gamma$-bw: TGATCTTGGAGCTGGCCTTA PIP5KI $\alpha$-fw: CCAACATAAAGAGGCGGAAT PIP5KI $\alpha$-bw: AGGGTTCTGGTTGAGGTTCAT PIP5KI $\beta$-fw: AGCAGCCTTGATGAAGAAGC PIP5KI $\beta$-bw: GAAGAAGATGAAATTGTGGTTGC PIP5KI $\gamma$-fw: AAGGAGGCCGAGTTCCTG PIP5KI $\gamma$-bw: CGGGTTCTGGTTGAGGTTC.

\section{Ethics statement}

The generation of K14-HPV8-E6 transgenic mice (FVB/n genetic background, Charles River Laboratories, Sulzfeld, Germany) and description of the UV irradiation protocol were described previously $[12,52]$. The generation of the transgenic mice and the UV irradiation protocols were approved by the governmental animal care office North-Rhine-Westphalia (protocol no. 8751.04.2010.A203) and were in accordance with the German Animal Welfare Act as well as the German Regulation for the protection of animals used for experimental purposes. EV skin lesions were removed during routine surgical excisions from which paraffin blocks were generated. The collection and analysis of EV skin was approved by the local ethics-committee at the Medical University of Warsaw, Poland. Tissue-micro-array (TMA) specimens of formalin-fixed, paraffin-embedded HPV16 positive CIN lesions (CINI-III and CC from individual patients) were obtained from the archive files of the Department of Pathology, University of Cologne. Clinical information was obtained from the patients' medical records. The collection of CIN lesions was realized according to BioMaSOTA votum (approval number 13-091) at the University of Cologne, Germany. Written informed consent, which was conducted in accordance with the Declaration of Helsinki, was obtained for the use of patient foreskin for isolation of primary keratinocytes. For biopsy materials from archival paraffin blocks of human Merkel cell carcinoma, basal cell carcinoma and malignant melanoma informed consent was obtained from all the subjects and ethical approval obtained from the Ethics Committee at the University of Cologne.

\section{Immunofluorescence staining of skin samples}

Four-micrometer formalin-fixed, paraffin-embedded sections were de-paraffinized with xylene. Samples were hydrated through a descending alcohol series and endogenous peroxidases were inactivated by incubation in $3 \% \mathrm{H}_{2} \mathrm{O}_{2}$ in methanol for $20 \mathrm{~min}$. Antigen unmasking was performed by boiling the tissue sections in $10 \mathrm{mM}$ citric buffer (pH6; for $\mathrm{PI}(4,5) \mathrm{P}_{2}$ and $\mathrm{H} 3 \mathrm{~K} 4 \mathrm{me} 3$ detection) for $3 \mathrm{~min}$ in a microwave followed by $15 \mathrm{~min}$ resting at RT. Blocking of unspecific antigen sites was achieved with 50\% goat serum (Thermo Scientific, Schwerte, Germany) in PBS for $1 \mathrm{~h}$ at RT. Incubation with primary antibody against $\mathrm{PI}(4,5) \mathrm{P}_{2}$ was done in a dilution of $1: 250$ in $2 \%$ goat serum over night at $4^{\circ} \mathrm{C}$. Detection of PI $(4,5)$ $\mathrm{P}_{2}$ antibodies was achieved by incubating the sections with a HRP-conjugated goat-anti-mouse-IgM antibody (Santa Cruz) diluted 1:1,000 in 2\% goat serum for $1 \mathrm{~h}$ at RT. The fluorescence signals were generated with the "TSA'T , Fluorescein System" (Perkin Elmer, Rodgau, Germany). After the sections were counterstained with 4',6-diamidino-2-phenylindole (DAPI) and embedded in Immunomount (Fisher Scientific, Schwerte) the 
specific signals were visualized by immunofluorescence microscopy using the Leica microscope DMI6000B, Leica camera DFC365FX and Leica Application Suite software v3.3.0.16799.

\section{Phosphoinositide extraction and quantification}

Phosphoinositide extraction was performed as described in [53] with a few modifications. Briefly, cell pellets were subjected to a two step neutral-acidic lipid extraction in the presence of $\mathrm{PI}(4) \mathrm{P}$ 17:0/20:4 and $\mathrm{PI}(4,5) \mathrm{P}_{2}$ 17:0/20:4 (Avanti Polar Lipids). Pellets were resuspended in $1 \mathrm{ml}$ chloroform/methanol $(1: 2, \mathrm{v} / \mathrm{v})$ and incubated for $10 \mathrm{~min}$ at RT. The sample was vortexed for 30 s every $3 \mathrm{~min}$. After precipitation $\left(13,800 \times \mathrm{g}, 2 \mathrm{~min}\right.$ at $\left.4^{\circ} \mathrm{C}\right)$, the supernatant was transferred to a new Eppendorf tube. For acidic extraction, the remaining pellet was resuspended in $750 \mu \mathrm{l}$ chloroform $/$ methanol $/ 37 \% \mathrm{HCl}(40: 80: 1, \mathrm{v} / \mathrm{v} / \mathrm{v})$ and incubated for $15 \mathrm{~min}$ at RT while vortexing the sample for $30 \mathrm{~s}$ every $5 \mathrm{~min}$. After transferring the tube to ice, $250 \mu \mathrm{l}$ cold chloroform and $450 \mu \mathrm{l}$ cold $0.1 \mathrm{M} \mathrm{HCl}$ was added followed by $1 \mathrm{~min}$ vortexing and centrifugation $(6,500 \times \mathrm{g}$, 2 min at $4^{\circ} \mathrm{C}$ ). The bottom organic phase was transferred to a new tube. An aliquot of the organic phase was adjusted to $10 \mathrm{mM}$ ammonium acetate in methanol and analyzed by mass spectrometric analysis on a QTRAP6500 (Sciex) equipped with CHIP-based infusion (Nanomate, Advion). Phosphoinositides were analyzed by positive ion mode neutral loss scanning selecting for fragment ions with $\mathrm{m} / \mathrm{z} 375$ phosphatidylinositol phosphate (PIP) and m/z 437 phosphatidylinositol-bisphosphate $\left(\mathrm{PIP}_{2}\right)$. Lipid quantification was done using LipidView software v1.2 by SCIEX.

\section{Proteomic analysis}

Proteomic analysis was performed as recently described [54]. Briefly, proteins immunoprecipitated using mouse anti-PI(4,5) $\mathrm{P}_{2}$ IgM antibodies were reduced by dithiothreitol $(100 \mathrm{mM})$ and alkylated (550 mM IAA) prior to digestion with trypsin and Lys-C overnight at $37^{\circ} \mathrm{C}$. Generated peptides were extracted by incubation with increasing amounts of acetonitrile, concentrated in a speed-vac and primed prior to liquid chromatography and tandem mass spectrometry (LC-MS/MS) analysis by the STAGE tip technique [55]. For LC-MS/MS an easy nLC 1000 (Thermo Scientific) was coupled to the quadrupole-based Q Exactive Plus (Thermo Scientific) instrument by a nano-spray ionization source. Peptides were separated on a $50 \mathrm{~cm}$ in-house-packed column by a two-solvent buffer system: buffer A ( $0.1 \%$ formic acid $)$ and B $(0.1 \%$ formic acid in acetonitrile). The content of buffer B was increased from $7 \%$ to $23 \%$ within 40 min and followed by an increase to $45 \%$ in $5 \mathrm{~min}$ and a washing and re-equilibration step before the next sample injection. The mass spectrometer operated in a Top 10 data- dependent mode using the following settings: MS1: 70.000 (at $200 \mathrm{~m}=\mathrm{z}$ ) resolution, 3e6 AGC target, $20 \mathrm{~ms}$ maximum injection time, 300-1.750 scan range; MS2: 35.000 (at $200 \mathrm{~m}=\mathrm{z}$ ) resolution, 5e5 AGC target, 108ms maximum injection time, $1.8 \mathrm{~m} / \mathrm{z}$ isolation window, 27 normalized collision energy. Bioinformatic analysis of all raw files was processed by MaxQuant 1.5.1.2 and Perseus 1.5.0.3.1.

\section{Statistical analysis}

All experiments were repeated a minimum of three times. All data from RT-qPCRs were expressed as mean \pm SEM. Results of the lipid analyses are presented as mean $\pm \mathrm{SD}$. The data presented as immunoblots or images of immunofluorescence analysis are from a representative experiment, which was qualitatively similar in the replicate experiments. Statistical significance was determined with unpaired 2-tailed Student's $t$-test. The asterisks shown in the figures indicate significant differences of experimental groups $\left({ }^{*} p<0.05 ;{ }^{* *} p<0.01,{ }^{* * *} p<0.001\right)$.

\section{Abbreviations}

HPV: human papillomavirus; SCC: squamous cell carcinoma; EV: Epidermodysplasia verruciformis; PHK: primary human keratinocyte; UV: ultra-violet; PI(4,5) $\mathrm{P}_{2}$ : phosphatidylinositol-4,5-bisphosphate; $\mathrm{PIP}_{2}$ : phosphatidylinositol-bisphosphate; PI: phosphatidy linositol; PI4P: Phosphatidylinositol-4-phosphate; PI5P: Phosphatidylinositol-5-phosphate; PIP5KI: phosphatidy linositol-4-phosphate-5-kinase type I; PIP4KII: phosphatidy linositol-5-phosphate 4-kinase type II; MAML1: Mastermind-like protein 1; RT-qPCR: reverse transcription quantitative PCR.

\section{Author contributions}

Be.M., M.H., T.S. and B.B. designed and performed the experiments. Bi.M. generated the tissue microarrays. P.Z. and S.M. provided human skin cancer sections. All the authors analyzed the data. B.A. designed, supervised the project and wrote the manuscript.

\section{ACKNOWLEDGMENTS}

The pXJ41-Flag or pXJ41-8E6-Flag constructs were kindly provided by Dr. G. Steger, Institute of Virology, University of Cologne, Germany. The authors would like to thank Matthias Kirschberg for carefully reading the manuscript.

\section{CONFLICTS OF INTEREST}

The authors declare no competing financial interests. 


\section{FUNDING}

This work was funded by The German Research Foundation (Deutsche Forschungsgemeinschaft (DFG), grant nr. AK42/4-1 (BA)) and by the Cologne Fortune Program (grant nr. 228/2016 (BA)). MH was supported by the German Cancer Aid (Deutsche Krebshilfe, grant nr. 70111087). BB was supported by the SFB/TRR83 and PZ by the SFB829.

\section{REFERENCES}

1. Schiffman M, Castle PE, Jeronimo J, Rodriguez AC, Wacholder S. Human papillomavirus and cervical cancer. Lancet. 2007; 370:890-907. https://doi.org/10.1016/ S0140-6736(07)61416-0.

2. Bouwes Bavinck JN, Feltkamp MC, Green AC, Fiocco M, Euvrard S, Harwood CA, Nasir S, Thomson J, Proby CM, Naldi L, Diphoorn JC, Venturuzzo A, Tessari G, et al, and EPI-HPV-UV-CA group. Human papillomavirus and posttransplantation cutaneous squamous cell carcinoma: A multicenter, prospective cohort study. Am J Transplant. 2018; 18:1220-30. https://doi.org/10.1111/ajt.14537.

3. Hasche D, Stephan S, Braspenning-Wesch I, Mikulec J, Niebler M, Gröne HJ, Flechtenmacher C, Akgül B, Rösl F, Vinzón SE. The interplay of UV and cutaneous papillomavirus infection in skin cancer development. PLoS Pathog. 2017; 13:e1006723. https://doi.org/10.1371/journal. ppat. 1006723.

4. Hufbauer M, Akgül B. Molecular Mechanisms of Human Papillomavirus Induced Skin Carcinogenesis. Viruses. 2017; 9:9. https://doi.org/10.3390/v9070187.

5. Majewski S, Jablonska S. Current views on the role of human papillomaviruses in cutaneous oncogenesis. Int J Dermatol. 2006; 45:192-96. https://doi. org/10.1111/j.1365-4632.2006.02758.x.

6. Howley PM, Pfister HJ. Beta genus papillomaviruses and skin cancer. Virology. 2015; 479-480:290-96. https://doi. org/10.1016/j.virol.2015.02.004.

7. Wallace NA, Galloway DA. Manipulation of cellular DNA damage repair machinery facilitates propagation of human papillomaviruses. Semin Cancer Biol. 2014; 26:30-42. https://doi.org/10.1016/j.semcancer.2013.12.003.

8. Brimer N, Lyons C, Wallberg AE, Vande Pol SB. Cutaneous papillomavirus E6 oncoproteins associate with MAML1 to repress transactivation and NOTCH signaling. Oncogene. 2012; 31:4639-46. https://doi.org/10.1038/onc.2011.589.

9. Meyers JM, Spangle JM, Munger K. The human papillomavirus type $8 \mathrm{E} 6$ protein interferes with $\mathrm{NOTCH}$ activation during keratinocyte differentiation. J Virol. 2013; 87:4762-67. https://doi.org/10.1128/JVI.02527-12.

10. Tan MJ, White EA, Sowa ME, Harper JW, Aster JC, Howley PM. Cutaneous $\beta$-human papillomavirus E6 proteins bind Mastermind-like coactivators and repress
Notch signaling. Proc Natl Acad Sci U S A. 2012; 109:E1473-80. https://doi.org/10.1073/pnas.1205991109.

11. Meyers JM, Uberoi A, Grace M, Lambert PF, Munger K. Cutaneous HPV8 and MmuPV1 E6 Proteins Target the NOTCH and TGF- $\beta$ Tumor Suppressors to Inhibit Differentiation and Sustain Keratinocyte Proliferation. PLoS Pathog. 2017; 13:e1006171. https://doi.org/10.1371/ journal.ppat.1006171.

12. Marcuzzi GP, Hufbauer M, Kasper HU, Weissenborn SJ, Smola S, Pfister H. Spontaneous tumour development in human papillomavirus type 8 E6 transgenic mice and rapid induction by UV-light exposure and wounding. J Gen Virol. 2009; 90:2855-64. https://doi.org/10.1099/vir.0.012872-0.

13. Hufbauer M, Cooke J, van der Horst GT, Pfister H, Storey A, Akgül B. Human papillomavirus mediated inhibition of DNA damage sensing and repair drives skin carcinogenesis. Mol Cancer. 2015; 14:183. https://doi. org/10.1186/s12943-015-0453-7.

14. Ganti K, Broniarczyk J, Manoubi W, Massimi P, Mittal S, Pim D, Szalmas A, Thatte J, Thomas M, Tomaić V, Banks L. The Human Papillomavirus E6 PDZ Binding Motif: From Life Cycle to Malignancy. Viruses. 2015; 7:3530-51. https://doi.org/10.3390/v7072785.

15. James CD, Roberts S. Viral Interactions with PDZ DomainContaining Proteins-An Oncogenic Trait? Pathogens. 2016; 5:5. https://doi.org/10.3390/pathogens5010008.

16. Lazić D, Hufbauer M, Zigrino P, Buchholz S, Kazem S, Feltkamp MC, Mauch C, Steger G, Pfister H, Akgül B. Human papillomavirus type 8 E6 oncoprotein inhibits transcription of the PDZ protein syntenin-2. J Virol. 2012; 86:7943-52. https://doi.org/10.1128/JVI.00132-12.

17. Mortier E, Wuytens G, Leenaerts I, Hannes F, Heung MY, Degeest G, David G, Zimmermann P. Nuclear speckles and nucleoli targeting by PIP2-PDZ domain interactions. EMBO J. 2005; 24:2556-65. https://doi.org/10.1038/ sj.emboj.7600722.

18. Fiume R, Stijf-Bultsma Y, Shah ZH, Keune WJ, Jones DR, Jude JG, Divecha N. PIP4K and the role of nuclear phosphoinositides in tumour suppression. Biochim Biophys Acta. 2015; 1851:898-910. https://doi.org/10.1016/j. bbalip.2015.02.014.

19. Divecha N, Banfić H, Irvine RF. The polyphosphoinositide cycle exists in the nuclei of Swiss 3T3 cells under the control of a receptor (for IGF-I) in the plasma membrane, and stimulation of the cycle increases nuclear diacylglycerol and apparently induces translocation of protein kinase $\mathrm{C}$ to the nucleus. EMBO J. 1991; 10:3207-14. https://doi. org/10.1002/j.1460-2075.1991.tb04883.x.

20. Boronenkov IV, Loijens JC, Umeda M, Anderson RA. Phosphoinositide signaling pathways in nuclei are associated with nuclear speckles containing pre-mRNA processing factors. Mol Biol Cell. 1998; 9:3547-60. https:// doi.org/10.1091/mbc.9.12.3547. 
21. Lewis AE, Sommer L, Arntzen MØ, Strahm Y, Morrice NA, Divecha N, D'Santos CS. Identification of nuclear phosphatidylinositol 4,5-bisphosphate-interacting proteins by neomycin extraction. Mol Cell Proteomics. 2011; 10:M110.003376. https://doi.org/10.1074/mcp.M110.003376.

22. Spector DL, Lamond AI. Nuclear speckles. Cold Spring Harb Perspect Biol. 2011; 3:3. https://doi.org/10.1101/ cshperspect.a000646.

23. Cocco L, Martelli AM, Gilmour RS, Ognibene A, Manzoli FA, Irvine RF. Rapid changes in phospholipid metabolism in the nuclei of Swiss 3T3 cells induced by treatment of the cells with insulin-like growth factor I. Biochem Biophys Res Commun. 1988; 154:1266-72. https://doi.org/10.1016/0006-291X(88)90276-8.

24. Divecha N, Banfić H, Irvine RF. Inositides and the nucleus and inositides in the nucleus. Cell. 1993; 74:405-07. https:// doi.org/10.1016/0092-8674(93)80041-C.

25. Shah ZH, Jones DR, Sommer L, Foulger R, Bultsma Y, D'Santos C, Divecha N. Nuclear phosphoinositides and their impact on nuclear functions. FEBS J. 2013; 280:6295310. https://doi.org/10.1111/febs.12543.

26. Choi S, Thapa N, Tan X, Hedman AC, Anderson RA. PIP kinases define $\mathrm{PI}, 5 \mathrm{P}_{2}$ signaling specificity by association with effectors. Biochim Biophys Acta. 2015; 1851:711-23. https://doi.org/10.1016/j.bbalip.2015.01.009.

27. Barlow CA, Laishram RS, Anderson RA. Nuclear phosphoinositides: a signaling enigma wrapped in a compartmental conundrum. Trends Cell Biol. 2010; 20:2535. https://doi.org/10.1016/j.tcb.2009.09.009.

28. Marx B, Miller-Lazic D, Doorbar J, Majewski S, Hofmann K, Hufbauer M, Akgül B. HPV8-E6 Interferes with Syntenin-2 Expression through Deregulation of Differentiation, Methylation and PhosphatidylinositideKinase Dependent Mechanisms. Front Microbiol. 2017; 8:1724. https://doi.org/10.3389/fmicb.2017.01724.

29. Dickson MA, Hahn WC, Ino Y, Ronfard V, Wu JY, Weinberg RA, Louis DN, Li FP, Rheinwald JG. Human keratinocytes that express hTERT and also bypass a p16(INK4a)-enforced mechanism that limits life span become immortal yet retain normal growth and differentiation characteristics. Mol Cell Biol. 2000; 20:143647. https://doi.org/10.1128/MCB.20.4.1436-1447.2000.

30. Thomas CL, Steel J, Prestwich GD, Schiavo G. Generation of phosphatidylinositol-specific antibodies and their characterization. Biochem Soc Trans. 1999; 27:648-52. https://doi.org/10.1042/bst0270648.

31. Osborne SL, Thomas CL, Gschmeissner S, Schiavo G. Nuclear PtdIns(4,5)P2 assembles in a mitotically regulated particle involved in pre-mRNA splicing. J Cell Sci. 2001; 114:2501-11.

32. Böhm S, Wilczynski SP, Pfister H, Iftner T. The predominant mRNA class in HPV16-infected genital neoplasias does not encode the E6 or the E7 protein. Int J Cancer. 1993; 55:791-98. https://doi.org/10.1002/ijc.2910550517.
33. van den Bout I, Divecha N. PIP5K-driven PtdIns(4,5)P2 synthesis: regulation and cellular functions. J Cell Sci. 2009; 122:3837-50. https://doi.org/10.1242/jcs.056127.

34. Martelli AM, Ognibene A, Buontempo F, Fini M, Bressanin D, Goto K, McCubrey JA, Cocco L, Evangelisti C. Nuclear phosphoinositides and their roles in cell biology and disease. Crit Rev Biochem Mol Biol. 2011; 46:436-57. https://doi.org/10.3109/10409238.2011.609530.

35. Attree O, Olivos IM, Okabe I, Bailey LC, Nelson DL, Lewis RA, McInnes RR, Nussbaum RL. The Lowe's oculocerebrorenal syndrome gene encodes a protein highly homologous to inositol polyphosphate-5-phosphatase. Nature. 1992; 358:239-42. https://doi.org/10.1038/358239a0.

36. Lemmon MA. Membrane recognition by phospholipidbinding domains. Nat Rev Mol Cell Biol. 2008; 9:99-111. https://doi.org/10.1038/nrm2328.

37. Balla T. Phosphoinositides: tiny lipids with giant impact on cell regulation. Physiol Rev. 2013; 93:1019-137. https://doi. org/10.1152/physrev.00028.2012.

38. Kunz J, Wilson MP, Kisseleva M, Hurley JH, Majerus PW, Anderson RA. The activation loop of phosphatidylinositol phosphate kinases determines signaling specificity. Mol Cell. 2000; 5:1-11. https://doi.org/10.1016/S1097-2765(00)80398-6.

39. Thapa N, Tan X, Choi S, Lambert PF, Rapraeger AC, Anderson RA. The Hidden Conundrum of Phosphoinositide Signaling in Cancer. Trends Cancer. 2016; 2:378-90. https://doi.org/10.1016/j.trecan.2016.05.009.

40. Halstead JR, van Rheenen J, Snel MH, Meeuws S, Mohammed S, D'Santos CS, Heck AJ, Jalink K, Divecha N. A role for PtdIns(4,5)P2 and PIP5Kalpha in regulating stress-induced apoptosis. Curr Biol. 2006; 16:1850-56. https://doi.org/10.1016/j.cub.2006.07.066.

41. Jones DR, Bultsma Y, Keune WJ, Halstead JR, Elouarrat D, Mohammed S, Heck AJ, D'Santos CS, Divecha N. Nuclear PtdIns5P as a transducer of stress signaling: an in vivo role for PIP4Kbeta. Mol Cell. 2006; 23:685-95. https://doi. org/10.1016/j.molcel.2006.07.014.

42. Chu KM, Minogue S, Hsuan JJ, Waugh MG. Differential effects of the phosphatidylinositol 4-kinases, PI4KII $\alpha$ and PI4KIII $\beta$, on Akt activation and apoptosis. Cell Death Dis. 2010; 1:e106. https://doi.org/10.1038/cddis.2010.84.

43. Bennett EJ, Rush J, Gygi SP, Harper JW. Dynamics of cullin-RING ubiquitin ligase network revealed by systematic quantitative proteomics. Cell. 2010; 143:951-65. https://doi.org/10.1016/j.cell.2010.11.017.

44. Rouillard AD, Gundersen GW, Fernandez NF, Wang Z, Monteiro CD, McDermott MG, Ma'ayan A. The harmonizome: a collection of processed datasets gathered to serve and mine knowledge about genes and proteins. Database (Oxford). 2016; 2016. https://doi.org/10.1093/ database/baw100.

45. Flick K, Kaiser P. Set them free: f-box protein exchange by Cand1. Cell Res. 2013; 23:870-71. https://doi.org/10.1038/ cr.2013.55 
46. Sundström JF, Vaculova A, Smertenko AP, Savenkov EI, Golovko A, Minina E, Tiwari BS, Rodriguez-Nieto S, Zamyatnin AA Jr, Välineva T, Saarikettu J, Frilander MJ, Suarez MF, et al. Tudor staphylococcal nuclease is an evolutionarily conserved component of the programmed cell death degradome. Nat Cell Biol. 2009; 11:1347-54. https://doi.org/10.1038/ncb1979.

47. Gutierrez-Beltran E, Denisenko TV, Zhivotovsky B, Bozhkov PV. Tudor staphylococcal nuclease: biochemistry and functions. Cell Death Differ. 2016; 23:1739-48. https:// doi.org/10.1038/cdd.2016.93.

48. Fashe T, Saarikettu J, Isomäki P, Yang J, Silvennoinen O. Expression analysis of Tudor-SN protein in mouse tissues. Tissue Cell. 2013; 45:21-31. https://doi.org/10.1016/j. tice.2012.09.001.

49. Akgül B, Karle P, Adam M, Fuchs PG, Pfister HJ. Dual role of tumor suppressor p53 in regulation of DNA replication and oncogene E6-promoter activity of epidermodysplasia verruciformis-associated human papillomavirus type 8 . Virology. 2003; 308:279-90. https://doi.org/10.1016/ S0042-6822(02)00133-2.

50. Hufbauer M, Biddle A, Borgogna C, Gariglio M, Doorbar J, Storey A, Pfister H, Mackenzie I, Akgül B. Expression of betapapillomavirus oncogenes increases the number of keratinocytes with stem cell-like properties. J Virol. 2013; 87:12158-65. https://doi.org/10.1128/JVI.01510-13.
51. Leverrier S, Bergamaschi D, Ghali L, Ola A, Warnes G, Akgül B, Blight K, García-Escudero R, Penna A, Eddaoudi A, Storey A. Role of HPV E6 proteins in preventing UVB-induced release of pro-apoptotic factors from the mitochondria. Apoptosis. 2007; 12:549-60. https:// doi.org/10.1007/s10495-006-0004-1.

52. Lazić D, Alborzi F, Marcuzzi GP, Angel P, Hess J, Pfister H, Akgül B. Enhanced StefinA and Sprr2 expression during papilloma formation in HPV8 transgenic mice. $\mathrm{J}$ Dermatol Sci. 2011; 62:84-90. https://doi.org/10.1016/j. jdermsci.2011.02.006.

53. Haag M, Schmidt A, Sachsenheimer T, Brügger B. Quantification of Signaling Lipids by Nano-Electrospray Ionization Tandem Mass Spectrometry (Nano-ESI MS/ MS). Metabolites. 2012; 2:57-76. https://doi.org/10.3390/ metabo2010057.

54. Saita S, Nolte H, Fiedler KU, Kashkar H, Venne AS, Zahedi RP, Krüger M, Langer T. PARL mediates Smac proteolytic maturation in mitochondria to promote apoptosis. Nat Cell Biol. 2017; 19:318-28. https:/doi. org/10.1038/ncb3488.

55. Rappsilber J, Ishihama Y, Mann M. Stop and go extraction tips for matrix-assisted laser desorption/ionization, nanoelectrospray, and LC/MS sample pretreatment in proteomics. Anal Chem. 2003; 75:663-70. https://doi. org/10.1021/ac026117i. 